\title{
Evaluation of Health Effects in Sequoyah Fuels Corporation Workers from Accidental Exposure to Uranium Hexafluoride
}

Manuscript (ompleted: April 1990)

Date Published: May 1990)

Prepared by

D. R. Fisher. M. J. Swint.' R. 1.. Kathren'

Pacific Northwest Laboratory

Richland, WA 99352

Prepared for

Division of Industrial and Medical Nuclear Safety Office of Nuclear Material Safety and Safeguards U.S. Nuclear Regulatory Commission Washington, DC 20555

NRC FIN B2:87-8

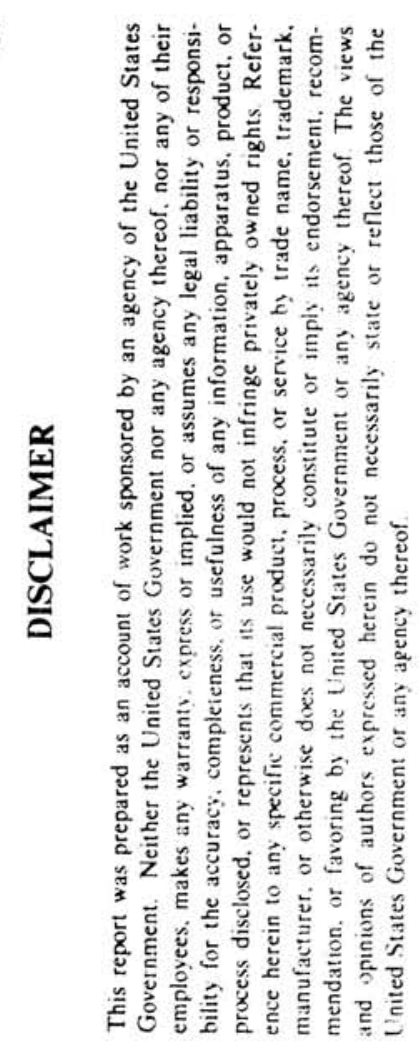

"Hanford Finvironmental Health Foundation Richland. WA 99352 


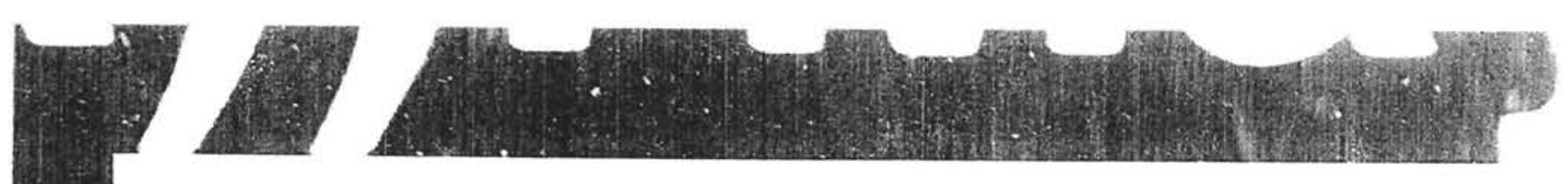

ABSTRACT

Urine bioassay ineasurements for uranium and medical laboratory resuits were studied to determine whether there were any health effects from uranium intake among a group of 31 workers exposed to uranium hexafluoride $\left(U F_{6}\right)$ and hydrolysis products following the accidental rupture of a 14-tun shipping cylinder in early 1986 at the Sequoyah Fuels Corporation uranium conversion facility in Gore, Oklahomia. Physiological indicators studied to detect kidney tissue damage included tests for urinary protein, casts and cells, blood, specific gravity, and urine $\mathrm{pH}$, blood urea nitrogen, and blood creatinine. We concluded after reviewing two years of follow-up medical data that none of the 31 workers sustained any observable health effects from exposure to uranium. The early excretion of uranium in urine showed more rapid systemic uptake of uranium from the lung than is assumed using the International Commission on Radiological Protection (ICRP) Publication 30 and Publication 54 models. The urinary excretion data from these workers were use to develop an improved systemic recycling model for inhaled soluble uranium. We estimated initial intakes, clearance rates, kidney burdens, and resulting radiation doses to lungs, kidneys, and bone surfaces. Radiation dose limits and limits on intake, as recommended by the ICRP, were not exceeded. However, the NRC derived limit of $9.6 \mathrm{mg}$ was exceeded by eight of the 31 workers. Maximum kidney concentrations in exposed workers ranged from 0.05 to $2.5 \mu_{\mathrm{y}} \mathrm{U} / \mathrm{g}$ kidney tissue. We found no toxicological effects on the kidneys of workers at these concentrations. 
Uranium urinalyses and medical laboratory results on plood and urine were studied to determine whether ihere were any health effects in 31 workers exposed to uranium hexafluoride $\left(\mathrm{UF}_{6}\right)$ following the accidental rupture of a 14-ton shipping cylinder in early 1986 at a uranium conversion facility in Gore, Oklahoma. The workers were likely exposed to very high concent rations of airborne uranium for short time periods. The most important short-term concern was inhalation of hydrofluoric acid (HF) with possible lung damage and skin-exposure burns. The major long-term concern was kidney dallage in workers with significant intakes of uranium. Urinalyses were performed on workers to evaluate their health and kidney function. The data were also evaluated to estimate their initial intakes of urarium, resulting radiation doses to bone surfaces, kidneys, and lungs, and the resulting committed effective dose equivalent (a measure of risk to the whole body).

The physiological indicators studied to detect kidney tissue damage by uranium poisoning included tests for urinary protein, casts and cells, urinary blood, specific gravity, pH of the urine, blood urea nitrogen, and blood creatinine. Physical examination and pulmonary function test resulis over a two-year follow-up period were also evaluated. We concluded from review of the medical records and laboratory results that none of the workers sustained any observable health effects from exposure to uranium during the accident. Some workers did suffer from short-term respiratory problems associated with inhalation of hydrogen fluoride (HF), and one worker succunbed enroute to a hospital. This report does not address, however, the health effects that may have been related to fluoride or hydrogen fluoride as a result of the accident.

The availability of uranium urinalysis data from a large number of acutely exposed subjects $(n=31)$ made it possible to learn more about the behavior of soluble uranium in the body. These urinalysis data were used to esiimate uranium irtakes, clearance rates, kidney burdens, and resulting radiation doses to lungs, kidneys, and bone surfaces. Dcsimetric analyses showed that neither the stochastic nor the nonstochastic annual limits on intake (ALI) for uranium, recommended by the International Commission on Radiological Protection in 1979, were exceeded, and that the calculated committed effective dose equivalents for workers were much less than nonstochastic exposure limit of $0.5 \mathrm{~Sv}$ (50 rem) to all tissues and the stochastic limit of $0.05 \mathrm{~Sv}(5 \mathrm{rem})$ to the whole body for internal emitters published by the ICRP in 1977 and 1979. The ICRP limits are based only on permitted radiation dose. However, the derived NRC 40-hour intake limit of $9.6 \mathrm{mg}$ soluble uranium in one work week was exceeded by eight of 31 workers.

The maximum kidney concentrations in exposed workers were estimated to range from 0.05 to $2.5 \mu \mathrm{g} \mathrm{U} / \mathrm{g}$ kidney tissue. No toxicological effects on the kidneys at coricentrations at or less than these amounts were observed in these workers according to our analysis of their clinical laboratory results. Although external chest-counts were performed on the workers about two weeks after the accident, the inhaled uranium had presumably already cleared from 
the lungs, and the chest-count measurements did not provide information useful for dose assessment.

The observed early excretion of uranium in urine indicated a more rapid clearance from the body than is assumed using the ICRP biokinetic model for soluble uranium compounds. A better fit of the SFC worker uranium excretion data to the ICRP lung model was obtained when the assumed clearance half-time from the pulmonary compartment to body fluids was changed in the model from 12 hours to 45 minutes. A systemic recycling model for uranium also fit the temporal pattern of the uranium excretion data better than did the ICRP systemic excretion model. Agreement between the urinary excretion data and the model was further improved by decreasing the clearance half-time of the kidneys from 15 days to 6 days. We called this revised biokinetic model for uranium, including the change in the pulmonary lung clearance half-time, the "modified" Wrenn model, and used it for dosimetric assessment of uranium intakes by the SFC workers. This modified model provided a better fit to the urinary excretion of acutely inhaled $U_{F}$ than did the ICRP biokinetic model.

The urinary uranium excretion function we derived from the short-term urinary excretion data was

$$
\begin{aligned}
y_{u}(t)= & 0.86 e^{-2.77 t}+0.0048 e^{-0.118 t}+0.00069 e^{-0.0287 t}+0.00017 e^{-0.00231 t} \\
& +2.5 \times 10^{-6} e^{-0.000187 t},
\end{aligned}
$$

where $y_{u}(t)$ is the expected fractional daily urinary excretion at time $t$ (days). The half-times of the five exponential components correspond to 0.25 days, 6 days, 26 days, 300 days, and 3700 days, respect.ively $\left(r^{2}=0.996\right)$.

The medical data and uranium bioassay data from exposed workers spanned a data-collection period of two years following the $U_{F}$ cyliacier-rupture accident. Our analys is of these data showed no evidence of long-term toxicological damage to kidneys of SFC workers, the primary health effect of concern from inhalation exposure to soluble uranium. 


\section{ACKNOWLEDGMENTS}

This study was initiated at the request of the U.S. Nuclear Regulatory Commission's (NRC) Office of Nuclear Material Safety and Safeguards.

Mr. W. Scott Pennington was the NRC Technical Project Manager.

Urinary excretion and clinical laboratory data were made available for this study by the Sequoyah Fuels Corporation (SFC) under the direction of the corpurate medical director, Dr. Evan R. Goltra. Lung counting data were provided by $\mathrm{Mr}$. Lee Lacy of SFC. The identity of individual workers was not provided and remains strictly confidential. Nonetheless, we express appreciation to these workers for providing numerous urine and blood samples on which the following report is based.

Uranium bioassay data were evaluated using GENMOD-PC, a commercial software package for internal dosimetry developed by Atomic Energy of Canada Limited (AECL), Chalk River, Ontario, Canada. Use of the GENMOD-PC software was permitted under a contractual arrangement between AECL and Pacific Northwest Laboratory.

We appreciate the extensive review comments of draft reports provided by the staff of the Nuclear Regulatory Commission, Dr. Keith F. Eckerman of the Health and Safety Research Division (Oak Ridge National Laborat.ory), and Prof. McDonald E. Wrenn of the Environmental Radiation \& Toxicology Laboratory (University of Utah). 


\section{CONTENTS}

ABSTRACT

i i i

SUMMARY

V

ACKNOWLEDGMENTS ................................. vii

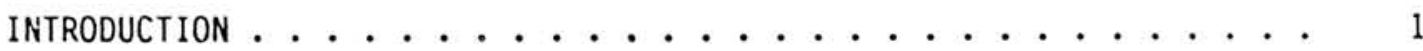

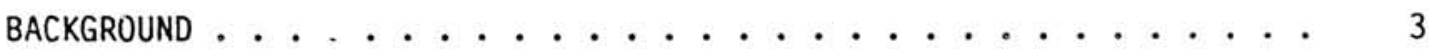

PRELIMINARY ANALYSES UF BIOASSAY RESULTS . . . . . . . . . . 3

FOLLOW-UP TESTING . . . . . . . . . . . . . . . . 4

ANALYSIS OF FOLLOW-UP DATA .............. 5

TOXICULOGY OF URANIUM .......................... 7

URANIUM BIOCHEMISTRY ................. 7

MECHANISM OF KIDNEY TISSUE DAMAgE .............. 8

MEDICAL INDICATCRS OF URANIUM TOXICITY . . . . . . . . . . . 11

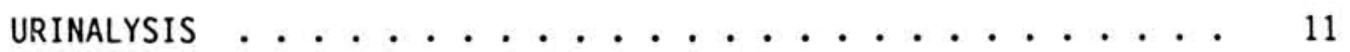

BLOOD ANALYSIS .......................... 12

PULMONARY FUNCTION STUDIES . . . . . . . . . . . . . 12

EVALUATION OF MEDICAL DATA . . . . . . . . . . . . . . . 15

FINDINGS ............................... 15

Urinalysis Data ......................... 16

Blood Tests ................... 16

Kidney Function Tests . . . . . . . . . . . 17

Pulmonary Function . . . . . . . . . . . . 17

EVALUATIONS OF FUTURE ACCIDENTAL EXPOSURES . . . . . . . 18

TREATMENT OF EXPOSED WORKERS . . . . . . . . . . . . . . . 18

COLLECTION OF COMPLETE URINE DATA . . . . . . . . . . . 19 
DOSIMETRIC EVÁLUATION OF SFC URANIUM BIOASSAY DATA . . . . . . . 21

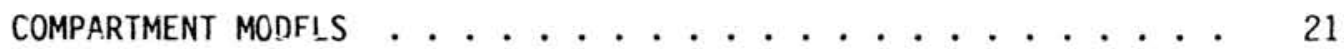

ICRP BIOKINETIC MODEL (1988) . . . . . . . . . . . . 22

GASTROINTESTINAL TRACT MODEL. . . . . . . . . . . . . 22

SYSTEMIC COMPARIMENT MODELS . . . . . . . . . . . . . . . . . 24

ICRP-30/54 Systemic Model . . . . . . . . . . . 24

Wrenn-Lipsziein-Bertelli Systemic Model ........ 25

METHOD OF DATA ANALYSIS . . . . . . . . . . . . . . 26

REFINEMENT OF THE WRENN-LIPSZTEIN-BERTELIII MODEL . . . . . . 27

COMPARISON OF THE ICRP-30/54 AND MODIFIED WRENN MODELS . . . . 28

Urinary Excretion Rates ............. . 28

Clearance of Uranium from Lungs . . . . . . . . . 28

Uranium Kidney Burdens . . . . . . . . . . . . 28

Uptake in Bone ................. 28

SELECTION OF THE MOCIFIED WRENN MODEL . . . . . . . . . . 28

DOSIMETRIC ANALYYSIS OF SFC WORKER URANIUM URINALYSES DATA . . . . 32

Daily Írinary Excretion Rate . . . . . . . . . . 32

Estimated Uranium Intakes ............. 34

Committed Effective Dose Equivalent . . . . . . . 35

Maximum Kidney Concentration ............. 36

Long-Term Integrated Kidney Retention ......... . 37

Estimates of Dose Equivalent to Tissues . . . . . . . 37

Chest Count Measurement Results . . . . . . . . . 37

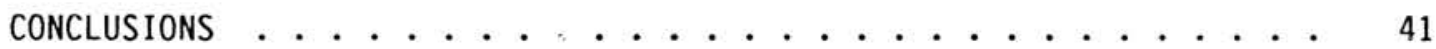

REFERENCES ........................... . . . . 43 


\section{FIGURES}

1 ICRP Biokinetic Model ................... 23

2 ICRP Systemic Model for Uranium . . . . . . . . . . . . 25

3 The Wrenn-Lipsztein-Bertelli Systemic Model for Uranium . . . . . 26

7 Comparison of the ICRP-30/54 and Modified Wrenn Urinary Excretion Functions for Uranium . . . . . . . . . . . . . 29

5 Retention of Class $D$ Uranium in the Lungs Accoraing to the ICRP-30/54 and Modified Wrenn Models . . . . . . . . . 29

6 Retention of Class $D$ Uranium in the Kidneys According to the ICRP-30/54 and Modified Wrenn Models . . . . . . . . . 30

7 Retention of Class $D$ Uranium in Bone According to the ICRP-30/54 and Modified Wrenn Models ........ . . 30

8 Plot of Individual Uranium Urinalysis Measurements, Normalized to the Initial Intake, for Ten SFC Workers . . . . . . 31

9 Uranium Excretion by SFC Worker E-1............... 33

10 Uranium Excretion by SFC Worker E-23 . . . . . . . . . . 33 


\section{$\underline{T A B L E S}$}

1 Urinary Indicators of Xidney Damage and Nurmal Ranges . . . . . . 12

2 CHEMSCAN $25 \mathrm{Clinical}$ Laboratory Tests on Blood Samples . . . . . 13

3 Compartmental Fractions and Clearance Half-times for Class D

Radioactive Materials . . . . . . . . . . . . . 24

4 Uranium Intakes, Committed Effective Dose Equivalent,

Maximum Kidney Concentration, and Long-term Integrated

Kidney Retention Estimated for SFC Workers Exposed to UF 6 . . . . 34

5 Comparison of Uranium Intakes Estimated for SFC Workers

in NUREG 1189, Volume 2, with Intake Estimates in Table 4

of this Report ................. 36

6 Estimated Organ Dose Equivalent for SFC Workers from the

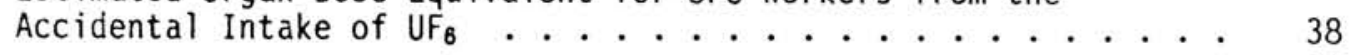

7 Results of In Vivo Chest-Count Measurements . . . . . . . . . 39 


\section{INTRODUCTION}

This report presents results of analyses of follow-up bioassay measurements and medical laboratory data on SFC workers involved in an accidental release of $U_{B}$ and hydrolysis products. The purpose of this scudy was to determine whether any health effects could be found in workers following their accidental acute exposure to uranium. Also included in this report are brief discussions of the basic mechanisms of uranium toxicity and medical indicators of uranium poisoning. The report summarizes two years of medical munitoring of exposed workers, and provides estimated intakes of uranium and resulting radiation doses. Dosimetric estimates were based on analys is of uranium cuncentrations in urine samples obtained from the workers during the four-week period immediately foilowing the accident. A revised biokinetic model was developed from these data and used to estinate uraniun intakes, uranium burdens in the lungs, kidneys, and bone, and effective dose equivalent for each worker involved in the accident.

The chemical form of the uranium released in the accident was uranium hexafluoride $\left(U_{B}\right)$. On contact with water vapor in air, $U_{F}$ hydrolyzes to $\mathrm{UO}_{2} \mathrm{~F}_{2}$ and hydrogen fluoride ( $\mathrm{HF}$ ), a highly acidic and corrosive compound. The early biological damage to workers accidentally inhaling the cloud ieleased by the cylinder rupture was due to acid burns and fluoride inhalation. We did not evaluate the health effects of fluorides or HF to workers as part of this study.

$\mathrm{UF}_{6}$ and $\mathrm{UO}_{2} \mathrm{~F}_{2}$ are highly soluble in lung fluids. After inhalation, these soluble uranium compounds are rapidly absorbed into circulating blood (the transfer compartment) and redistributed throughout the body. Uranium dissolves in body fluids by forming the uranyl ion $\left(\mathrm{UO}_{2}{ }^{++}\right)$, which is resorbed by the kidneys during filtration of circulating blood. $\mathrm{UO}_{2}{ }^{++}$interferes with the transport of nutrients through cell walls and causes cell death, which leads to kidney damage.

The chemical properties of $\mathrm{UF}_{\mathrm{B}}$ and $\mathrm{UO}_{2} \mathrm{~F}_{2}$ influence their distribution in body tissues, their residence times, and ultimately their chemical to.icity and the radiation dose imparted to tissues. Uranium toxicology and dosimetry are furtiier discussed in the following sections as part of the analys is of health effects in workers accidentally exposed to $U F_{B}$ following the 1986 cylinder-rupture accident. 
A 14-ton Model 48Y cylinder containing approximately 29,500 pounds of $U_{6}$ ruptured in a steam chest at the Sequoyah Fuels Corporation (SFC) facility at Gore, Oklahoma, on January 4, 1986, at about 11:30 a.m. (Nn? 1986a,b). The accident occurred when the over-loaded shipping cylinder was , sheated to remove an excess of uranium hexafluoride $\left(U F_{6}\right)$. When the cylinder ruptured, a dense, white clcud of $\mathrm{UF}_{6}$ and its reaction products uranyl fluoride $\left(\mathrm{UO}_{2} \mathrm{~F}_{2}\right)$ and hydrofluoric acid (HF) were released into the air. A number of SFC workers and on-site contractor personnel were exposed to the hot cloud and received intakes of both soluble uranium and $\mathrm{HF}$. One worker succumbed to massive pulmonary edem. from inhalation of HF. One other worker was treated for skin irritation and burns from HF. Twenty-one workers were examined at the Sequoyah Memorial Hospital in Sallisaw, Oklahoma, and retained overnight for observation. Of this number, four were released the following morning, 14 were retained more than one day and given sodium bicarbonate as AlkaSeltzero, and three were examined and transferred to Sparks Memorial Hospital, Ft. Smith, Arkansas, for observation relative to possible lung irritation and/or lung damage from exposure to HF (NRC 1986b, Pp. 405-406).

Urine samples were collected from the exposed workers at the hospital to determine the extent of personnel exposures to uranium as a result of the accident. The earliest urine samples for uranium analys is were obtained 4.5 to 8 hours after the accident. Additional urine samples were obtained from the workers at various times over the next few days and submitted to a chemistry laboratory for fluorometric uranium analysis. Urine samples collected from about day 4 after the accident and periodically for about the next two years were also analyzed for specific gravity, $\mathrm{pH}$, protein, glucose, cells, casts, yeast, bacteria, ketones, and blood. Blood samples were analyzed for urea nitrogen and creatinine for incications of possible kidney tissue damage. The results of pulmonary function tests and periodic complete medical examinations of the worker population were also studied.

\section{PRELIMINARY ANALYSES OF BIOASSAY RESULTS}

Early uranium urinalysis results were transmitted by facsimile to three Department of Energy (DOE) laboratories: Pacific Northwest Laboratory (PNL), Richland, Washington; Oak Ridge National Laboratory (ORNL), Oak Ridge, Tennessee; and Brookhaven National Laboratory (BNL), Upton, Long Island, New Yorik. Within the next 24 hours, preliminary estimates of uranium intakes by SFC workers, several contractor personnel, and some members of the exposed off-site general public were telecopied back to the NRC. Results of those preliminary calculations subsequently appeared in Appendix 5.6.3 of a Nuclear Regulatory Commission (NRC 1986a) assessment of the public health impact from the accidental release.

B Registered trademark of Miles, Inc., Elkhart, Indiana. 
Considering the sparsity of the early data and rapid turn-around time required, there was remarkable agreement between the preliminary estimates of intake calculated independently by the three DOE laboratories. The urinary excretion data provided to the laboratories were given in concentration units of micrograms ( $\mu \mathrm{g})$ uranium per liter (L) urine, and the times of urine coliection were also given, but the total urinary excretion volumes per day were not known. Each laboratory therefore assumed that the average urinary excretion of sach worker was equivalent to that of Reference Man (ICRP 1975), $1.4 \mathrm{~L}$ per day: and that measured values were representative of the rate of uranium elimination. The DOE iaboratories also assumed that the inhaled uranium consisted of particulates with an activity median aerodynamic diameter (AMAD) \& $\quad 1.0 \mu \mathrm{m}$ and that it was highly soluble in lung fluids (ICRP class $D$ compound). PNL used the ICRP- 30 metabolic rat $\epsilon$ constants given in Publication 30 of the International Commission on Radiological Protection (ICRP 1979) to describe early clearance from lung and transfer to blood and averaged the intake estimates for each time point at which a urine sample was obtained. BNL applied the same ICRP-30 metabolic rate constants but used a least-squares method for fitting excretion data to estimates of intake for each sampling time point. ORNL assumed that $50 \%$ percent of the inhaled activity was trarislocated to body fluids ( $30 \%$ with a halt-time of 0.01 days and $20 \%$ with a half-time of 0.5 days). ORNL also assumed a more rapid early clearance ( $T \frac{1}{2}=0.01$ days or 15 minutes) to blood for $30 \%$ of the material deposited in the lung and fit the urinary excretion to the function

$$
y_{u}(t)=7.3 e^{-0.2 t}+2.4 e^{-0.075 t}+0.08 e^{-0.011 t}+0.004 e^{-0.0014 t} \text {, }
$$

where $y_{u}(t)$ was the percent per hour excreted in urine and $t$ was the time in hours (NRC 1536a). The ORNL fuliction approximated the urinary excretion for times from 30 minutes to several days post-accident.

Among the 31 workers sampled, the highest intake was estimated for worker No. 17 (average estimate of the three laboratories $=27.6 \mathrm{my} \mathrm{U}$ ), and the lowest intake was estimated for worker No. 21 (average estimate = $0.26 \mathrm{mg} \mathrm{U}$ ). The mean intake for all exposed workers was estimated to be about $7.3 \mathrm{mg} \mathrm{V}$.

\section{FOLLOW-UP TESTING}

The NRC subsequentily issued an amendment to the SFC'S facility operating license requiring a comprehensive employee monitoring program for those workers exposed to uranium during the January 4, 1986, accident. As a minimum, the monitoring program: was to include:
1) semimonthly quantitative urinalyses for uranium,
2) semimonthly urinalyses for physiological indicators, including specific gravity, pH, protein, ketones, casts and cells, and urinary blood, and analyses for blood urea nitrogen,
3) semiannual pulmonary function testing, and 
4) annual routine physical examinations.

One purpose of the above monitoring requirements was to coilect data that might incicate whether or not workers exposed to uranium during the accident could hav s sustained any health effects such as tissue damage to kidneys.

of the thirty-one employees deemed to have been potentially exposed to uranium Juring the accident, twenty-six were monitored for the full two-year period, four terminated employment early, and one was judged not to have been in the facility at the time of the accident.

A comprehensive set of confidential urinalysis and medical monitoring data were provided to the NRC by SFC on or just prior to July 1, 1988.

\section{ANALYSIS OF FOLLOW-UP DATA}

Pacific Northwest Laboratory, in conjunction with the United States Uranium Registry (operated by the Hanford Environmental Health Foundation for the U.S. Department of Energy), was asked to review the urine bioassay results and medical data from clinical analyses provided by SFC to the NRC. The purpose of this review was to

1) determine whether these data indicated evidence of kidney damage or other biological effects attributable to uranium,

2) estimate initial intakes and subsequent lung burdens, and

3) evaluate time-averaged kidney concentrations of uranium and resulting radiation doses to internal organs.

Brookhaven National Laboratory and Oak Ridge National Laboratory were invited to participate in the analysis of the SFC data but elected not to do so.

The review of these data stbsequently required a new look at biokinetic models used to estimate the intake, retention, and clearance of uranium in people. There are few published data on the short-term excretion of soluble uranium following accidental acute exposures. The large number of subjects (31) that experienced the 1986 accidental uranium exposure made it possible to develop a revised biokinetic model to describe the behavior of soluble $U_{B}$ in the body. Therefore, a discussion of biokinetic models, model parameters, and comparison of models is presented in this report to justify selection of a revised biokinetic model for assessing the intakes, organ burdens, and radiation doses to the SFC workers. 


\section{TOXICOLOGY OF URAN:UM}

Much has been written on the chemical and radiological effects of uranium in people, and it is not the purpose of this report to present a comprehensive treatise on the subject. Several major reviews on the toxicology of uranium compounds have been published in recent years, including an excellent summary on uranium metabolism and its acute and chironic toxicity (Durbin and Wrenn 1975), two books summarizing the animal and human studies on uranium by Hodge, Stannard, and Hursh (1973) and Stannard (1988), and an excellent review of metabolic models for uranium (Durbin 1984). The physical and chemical properties of uranium have also been discussed in depth by Gindler (1973). The behavior and chemical toxicity of uranium in kidney tissue was also extensively reviewed by Leggett (1989). Some of the most important aspects of uranium toxicology are summarized in the following sections.

\section{URANIUM BIOCHEMISTRY}

The biochemical behavior of uranium compounds inside the body is fairly complex. A basic knowledge of uranium biochemistry is essential to fully appreciate and understand the toxicological effects of uranium on people. Some of the chemical properties of uranium and its biochemistry are given below.

At room temperature, $U F_{B}$ is a white, volatile solid with a low melting temperature $\left(64^{\circ} \mathrm{C}\right)$. Liquid $\mathrm{UF}_{B}$ is a dense, colorless liquid. $U \mathrm{~F}_{B}$ is a highly reactive compound that reacts chemically with water, ether, and alcohol to form soluble reaction products. It elso reacts with some metals. It does not react with oxygen, nitrogen, or dry air. Airborne uranium hexafluoride $\left(U F_{B}\right)$ hydrolyzes rapidly on contact with moisture in air to form uranium oxyfluoride $\left(\mathrm{UO}_{2} \mathrm{~F}_{2}\right)$ and hydrofluoric acid (HF); the reaction is shown stoichiometrically as:

$$
\mathrm{UF}_{6}+2 \mathrm{H}_{2} \mathrm{O} \rightarrow \mathrm{UO}_{2} \mathrm{~F}_{2}+4 \mathrm{HF}+52 . ? \mathrm{kcal} / \mathrm{mole}
$$

$\mathrm{HF}$ is a strong acid that may cause burns of the eyes, skin, and respiratory tract, if inhaled. The $\mathrm{UO}_{2} \mathrm{~F}_{2}$ compound forms a heavy aerosol that may be carried by wind and then settle out onto ground or other surfaces.

Hexavalent uranium compounds, such as $\mathrm{UF}_{8}$ and $\mathrm{UO}_{2} \mathrm{~F}_{2}$, are quite soluble in the lung and are therefore rapidly absorbed into the blood following inhalation. Thus, they have been assigned to inhalation class $D$ by the ICRP (ICRP 1979). Hexavalent uranium oxide $\left(\mathrm{UO}_{3}\right)$ and the tetravalent uranium compounds $\mathrm{UF}_{4}$ and $\mathrm{UCl}_{4}$ are more slowly absorbed and are assigned to inhalation class $W$. Oniy a small fraction of the soluble uranium ( +6 valence) entering the gastrointestinal tract either from ingestion or by mucociliary clearance of inhaled particles is absorbed into the blood. This fraction has been estimated to be $1-2 \%$ by Durbin (1984) and Wrenn et al. (1985), although the ICRP published an $f_{1}$ value (the transfer fraction from gut to blood) of 
$0.05(5 \%)$ for class D and class W uranium compounds (ICRP 1979, 1988). The remainder is excreted in the feces.

The insoluble uranium oxides $\mathrm{UO}_{2}$ and $\mathrm{U}_{3} \mathrm{O}_{8}$ are considered to be inhalation class $Y$ materials (ICRP 1979, 1988). Uranium in the +4 state slowly oxidizes to the +6 state in body tissues and fluids. Insoluble uranium nay remain for years in the lungs and associated lymph nodes, and if sufficiently great in amount may result in pulmonary metaplasia and shrinkage of lymph tissues. Insoluble dusts are cleared from the respiratory tract by mucociliary clearance to the gastrointestinal tract where uranium is only poorly absorbed into the blood; the $f_{1}$ value for class $Y$ uranium given by the ICRP is 0.002 , or $0.2 \%$ (ICRP 1979,1988 ).

$\mathrm{UO}_{2} \mathrm{~F}_{2}$ is rapidly absorbed from the lung into the blood stream as the $\mathrm{UO}_{2}{ }^{++}$ion, which behaves much like calcium and complexes with serum proteins and bicarbonate. The uranyl ion forms biscarbonate, $\mathrm{UO}_{2}\left(\mathrm{CO}_{3}\right)_{3}^{--}$, and citrate complexes in blood plasma (Durbin 1984). $\mathrm{UO}_{2}{ }^{++}$also binds to red blood cells. As it passes through the kidneys and is filtered from blood, the $\mathrm{UO}_{2}{ }^{++}$ion dissociates within the tubular filtrate and recombines with cell surface ligands (Morrow 1984). Removal of the uranyl ion from the kidneys has been described by a two-component exponential model indicating that $92-95 \%$ is excreted in the urine with a half-time of 2-6 days, and the remainder with a half-time of 30-340 days (Durbin 1984). Wrenn, Lipsztein, and Bertelli (1989) showed from a variety of mammalian laboratory experiments that the short-term retention of uranium in the kidneys should range from two to six days. Their earlier model used a clearance half-time of 15 days.

Uranium absorbed into the blood is mostly excreted in the urine. There is some generalized systemic deposition in the soft tissues, primarily the liver, as well as in the skeleton (Fisenne and Welford 1986; Kathren et al. 1989). Bone is the primary target organ for systemic $\mathrm{UO}_{2}{ }^{++}$, where it replaces calcium $\left(\mathrm{Ca}^{++}\right)$on crystalline surfaces. Deposition rates in bore correlate with bone growth and remodeling ratej. Recirculating $\mathrm{UO}_{2}{ }^{++}$from bone replenishes the uranium in kidneys. Long-term retention cf uranium in bone is characterized by two compartments; approximately $90 \%$ of uranium deposited in bone is cleared with a half-time of 20-300 days, and the remainder is cleared with a half-time of 3700-5000 days (Durbin 1984; ICRP 1979,1988 ).

\section{MECHANISM OF KIDNEY TISSUE DAMAGE}

The normal, undamaged proximal tubules act on the glomerular filtrate and reabsorb water, glucose, amino acids, and proteins that have filtered through the glomeruli. These compounds plus electrolytes are returned to blood plasma. The $\mathrm{UO}_{2}{ }^{++}$ion on cell surfaces interferes with the transport of nutrients through the cell membrane, which can result in ceil death and functional loss in the kidneys. Shedding of these cells may be accompanied by excretion of uranium from the kidneys into urine.

Tissue damage to the renal proximal tubules is rapid and may occur within 24 hours of exposure to uranium. Water consumption by the subject 
normally then increases due to thirst, and urinary output may multiply by as much as a factor of five. Tissue damage leading to functional loss is indicated by failure to resorb, leading to increased excretion of urinary protein, glucose, catalase, phosphate, citrate, and creatinine (Morrow et al. 1982). Glycosuria without elevated blood glucose is alsu associated with renal tubular dysfunction. The tissue damage is termed "nephritis," and is characterized by morphological changes, enzymuria, glycosuria, and increased excretion of amino acids and small proteins in the urine (proteinuria). The urinary excretion of proteins, amino acids, enzymes, and glucose may be a quan:itative as well as a qualitative indicator of uranium poisoning (Fisher 1988).

Large intakes of uranium may cause albuminuria and acute renal failure. The regeneration of damaged tubules has been observed in animal studies but not demonstrated in humans. In animals, regeneration may begin within two to three days and was completed within a few weeks (Yuile 1973). Human kidneys appeared to tolerate chemical nephrotoxicity better than other inammalian species. The LDso/30 (lethal dose to $50 \%$ of the population over a 30 -day period) in reople is thought to be $1-2 \mathrm{mg} \mathrm{U} / \mathrm{kg}$ body weight (or about 70-140 $\mathrm{mg} U$ in a standard human) (Lincoln and Voelz 1988).

There is a gradual decline in urinary nutput and glucose and protein excretion following acute exposure to uranium, suggesting a possible repair process and regeneration of the tubules. However, the injury to kidney tissues is not necessarily transient or reversible. If a critical mass of kidney cells dies, the kidneys cease to function. Damaged cells are replaced by atypical new cells lacking the functional ability of those that were lost (Wrenn et al. 1985). Although some functions may appear normal, tolerance by recovery has not been uniformly observed in animal experiments, indicating that the kidneys may remain impaired following severe uranium exposure.

Howland (1949) reported an acute $U F_{B}$ exposure accident involving 21 workers in 1944 that involved fluoride inhalation and acid burns. The most heavily exposed of the survivors showed albumin, red cells and casts in microscopic urine for three days, as well as increased blood urea for three weeks following the accident. The peak urinary excretion of uranium for two of the three most acutely injured workers ranged from $0.15-0.5 \mathrm{mg} \mathrm{U} / \mathrm{L}$. On evaluation 38 years later, the same two workers showed no detectable uranium deposition or physiological damage related lo their uranium exposure (Kathren and Moore 1986). One of the exposed individuals showed an altered clearance pattern for uranium shortly after the accident, possibly from pulmonary edema associated with concomitant exposure to acid fumes.

The renal injury threshold is estimateu to be $10 \mu \mathrm{g} \mathrm{U}$ (as $\mathrm{UO}_{2} \mathrm{~F}_{2}$ ) $/ \mathrm{kg}$ (body weight) for dogs and about $100 \mu \mathrm{g} \mathrm{U} / \mathrm{kg}$ for rats (Morrow et al. 1982). The threshold level for injury in humans is thought to be about $70 \mu \mathrm{g} / \mathrm{kg}$ (body weight), between that for dogs and rats. This value corresponds to a renal injury threshold concentration of $16.3 \mu \mathrm{g} \mathrm{U} / \mathrm{g}$ of human kidney tissue. However, typical indicators of uranium poisoning have been obtained with concentrations of $3 \mu \mathrm{g} \mathrm{VO}{ }_{2}^{++} / \mathrm{g}$ (tissue) in animal kidneys over extended periods of time (Morrow et al. 1982). This finding caused the NRC to reevaluate its derived kidney-tissue exposure limit of $3 \mu \mathrm{g} \mathrm{U} / \mathrm{g}$ tissue for 
uranium workers based on previous uranium toxicity studies in animals (Hursh and Spoor 1973, Hodge 1973). The NRC considered a factor of six reduction (to $0.5 \mu \mathrm{g} \mathrm{U} / \mathrm{g}$ kidney tissue) to protect workers from uranium nephrotoxicity.

The toxicity threshold for long-term uptake by the kidneys is not well known. Wrenn et al. (1985) reviewed the metabolism and kidney toxicity of ingested uranium in humans and concluded that for chronic intakes, the chemical toxicity threshold for the kidney may lie between 1 and $3 \mu \mathrm{g} \mathrm{l} / \mathrm{g}$ kidney tissue. Kocher (1989) reviewed the implications of a $1 \mu \mathrm{g} \mathrm{U} / \mathrm{g}$ kidney tissue threshold chemical toxicity level with respect to regulatory limits, concluding that chemical toxicity should be considered in developing protection standards for the public for ingestion of natural or depleted uranium. 
This section describes medicai tests for evaluating the degree of chemical toxicity that may result from inhalation exposure to uranium by workers. Specific tests for evaluating potential kidney damage or lung damage are describe below.

\section{URINALYSIS}

The kidneys perform many essential metabolic functions, including filtering nitrogenous wastes and other materials from the blood, maintaining electrolyte balance, and regulating the physiological acidity-alkalinity balance. The location and nature of different kidney disorders may be interpreted by analysis of the urine content. Table 1 lists the urine tests performed on SFC workers to assess their renal function.

Urinalysis is a primary test for evaluating renal function and possible chemical toxicity from uranium poisoning. Urinary excretion of either $\beta-2$ microglobulin or catalase relative to creatinine excretion are sensitive indicators of renal dysfunction in humans and animals poisoned by uranium; however these tests were not specifically performed on SFC workers. Other indications of kidney toinicity may be inferred from tests for albumin or amino acids and microscopic exannination for casts and cellular debris. Casts are cylindrical masses of protein formed in renal tubules that may be observed upon microscopic examination of urine. Cellular and granular elements in casts may indicate damaged tubular cells that have disintegrated and combined with protein. The most comnon cast protein, albumin, is associated with renal tubular dysfunction and glomerulonephritis.

The urine may also be analyzed for specific gravity. The ability to concentrate urine diminishes when there is selective damage to the medulla or tubular epithelium even if total kidney function is not affected. Renal concentrating ability is evaluated easily by measuring the specific gravity of urine. In the absence of excess protein or glucose, a specific gravity of about $1.025(\mathrm{~g} / \mathrm{mL})$ indicates that the concentrating ability is normal. Test results outside the normal range of 1.001 to $1.035(\mathrm{~g} / \mathrm{mL})$ indicate a changed renal capability (Widmann 1983). Clinica' laboratory norma? values are typically in the range of 1.010 to $1.025(\mathrm{~g} / \mathrm{mL})$. Uranium-induced nephritis could inhibit the ability of the kidneys to concentrate uranium, resulting in urine with continuous low specific gravity.

Urinary glucose levels may increase as a result of kidriey tissue damage. For example, Acquired Fanconi Syndrome may be caused by defects in tubular reabsorption and may be induced by heavy metal poisoning, including acute exposure to uranium. This effect is indicated by glycosuria. Thus, damage to the proximal tubules mav lead to increased urinary excretion of sugar. The sugar level in circulating blood, however, is not affected by uranium poisoning. 
TABLE 1. Urinary Indicators of Kidney Damage and Normal Ranges

\begin{tabular}{l}
\multicolumn{1}{c}{ Analysis } \\
\hline Specific Gravity \\
Acidity/Alkalinity (pH) \\
Protein (albumin) \\
Glucose \\
White Blood Cells \\
Red Blood Cells \\
Casts \\
Yeast \\
Ketone Bodies \\
Bacteria
\end{tabular}

\begin{tabular}{l} 
Normal Range \\
\hline $1.010-1.025$ (water $=1.00$ ) \\
$4.8-7.5$ \\
$5-10 \mathrm{mg} / \mathrm{dL}$ \\
$<50 \mathrm{mg} / \mathrm{dL}$ \\
$0-2 \mathrm{per}$ field of view \\
$0-3 \mathrm{per}$ field of view \\
none to few per field \\
none to occasional \\
none to trace amounts \\
none to occasional
\end{tabular}

Protein and glucose testing of urine should be conducted at early times (3-7 days) following an acute exposure to uranium. Testing at later times may miss these indicators if damage is not severe.

\section{BLOOD ANALYSIS}

Blood analysis shows concentrations of enzymes, proteins, sugars, acids, and cholesterol, and helps to identify physiological indicators of abnormal body function or health-related problems. The CHEMSCAN 25 profile of 25 separate tests is commonly requested as a part of routine and special physical examinations (Table 2). Blood urea nitrogen and blood creatinine are two of the CHEMSCAN 25 tests that are relevant to indications of the chemical toxicity of uranium.

Blood urea nitrogen (EUN) reflects the balance between production and excretion of protein. Urea concentrations usually remain fairly constarit within the normal ser: $\mathrm{m}$ range of $8-25 \mathrm{mg} / \mathrm{dL}$, with higher levels indicating uremid. The most common cause of increased blcod urea nitrogen is renal failure.

Blood creatinine is proportional to ske,etal muscle present and indicates creatinine metabolism. Blood creatinine remains fairly constant in the normal range of $0.6-1.3 \mathrm{mg} / \mathrm{dL}$, except following crush injury or degenerative muscle damage. Blood creatinine levels may also rise when renal function declines. During severe, permanent renal impairment, creatinine levels plateau while blood urea nitrogen continues to increase. However, elevated blood urea nitrogen with normal creatinine signals a non-renal cause for uremia.

\section{PULMONARY FUNCTION STUDICS}

Pulmonary function testing measures the forced vital capacity of the lungs and indicates the health of the lungs in comparison to normal subjects of similar age and weight. Two parameters are measured: the forced 
TABLE 2. CHEMSCAN 25 Clinical Laboratory Tests on Blood Samples

\begin{tabular}{|c|c|}
\hline Analysis & Normal Range \\
\hline $\begin{array}{l}\text { Glucose } \\
\text { Blood Urea Nitrogen (BUN) } \\
\text { Creatinine } \\
\text { BUN/Creatinine ratio } \\
\text { lric Acid } \\
\text { Cholesterol } \\
\text { Triglycerides } \\
\text { Creatine Phosphokinase } \\
\text { Lactic Dehydrogenase } \\
\text { Serum Aspartate Aminotransferase } \\
\text { Serum Alanine Aminotransferase } \\
\text { Alkal ine Phosphatase } \\
\text { Gamma Glutamyltransferase } \\
\text { Total Bilirubin } \\
\text { Total Protein } \\
\text { Albumin } \\
\text { Globulin } \\
\text { Albumin/Globulin Ratio } \\
\text { Calcium } \\
\text { Inorganic Phosphates } \\
\text { Sodium } \\
\text { Potassium } \\
\text { Chloride } \\
\text { Carbon Dioxide } \\
\text { Anion Gap } \\
\text { Iron }\end{array}$ & $\begin{array}{l}65-115 \mathrm{mg} / \mathrm{dL} \text { (fasting) } \\
8-23 \mathrm{mg} / \mathrm{dL} \\
0.8-1.4 \mathrm{md} / \mathrm{dL} \text { (adult male) } \\
8-22 \text { (adult) } \\
3.5-8.5 \mathrm{mg} / \mathrm{dL} \text { (adult male) } \\
150-240 \mathrm{mg} / \mathrm{dL} \text { (fasting) } \\
30-175 \mathrm{mg} / \mathrm{dL} \text { (fant } \\
0-120 \mathrm{units} / \mathrm{L} \\
60-200 \mathrm{units} / \mathrm{L} \text { (adult) } \\
0-30 \mathrm{units} / \mathrm{L} \\
0-40 \mathrm{units} / \mathrm{L} \\
30-110 \mathrm{units} / \mathrm{L} \text { (adult) } \\
0-38 \mathrm{units} / \mathrm{L} \text { (male) } \\
0.1-1.2 \mathrm{mg} / \mathrm{dL} \\
6.0-8.2 \mathrm{~g} / \mathrm{dL} \\
3.5-5.0 \mathrm{~g} / \mathrm{dL} \\
2.0-4.0 \mathrm{~g} / \mathrm{dL} \\
1.1-2.4 \mathrm{mg} / \mathrm{dL} \\
8.5-10.5 \mathrm{mg} / \mathrm{dL} \\
2.5-4.5 \mathrm{mg} / \\
135-145 \mathrm{mEq} / \mathrm{L} \\
3.5-5.0 \mathrm{mEq} / \mathrm{L} \\
100-110 \mathrm{mEq} / \mathrm{L} \\
24-30 \mathrm{mEq} / \mathrm{L} \\
5-17 \\
40-145 \mathrm{mEq} / \mathrm{dL}\end{array}$ \\
\hline
\end{tabular}

expiratory volume in one serond, and the total forced expiratory volume. Pulmonary function is best measured at several points over time for trend analysis. The test will indicate signs of obstructive or restrictive disease, which can occur as a result of lung injury or chronic illness. Test results are typically given as a percentage of the expected normal value. 


\section{EVALUATION OF MEDICAL DATA}

As noted previously, the minimum post-accident, license-condition monitoring program followed by SFC on the affected workers included:

1) a semimonthly quantitative urine bioassay for uranium,

2) a semimonthly urinalys is for physiologic parameters, including specific gravity, $\mathrm{pH}$, protein, ketones, blood and nitrate presence, and microscopic examinations of urine for the presence of casts and cells,

3) a seiniannual pulmonary function testing, and

4) an annual routine physical examination.

Periodic CHEMSCAN 25 tests and complete blood count (CBC) were also obtained by SFC on the exposed workers.

Medical records prepared by SFC were given to the NRC and subsequently provided to the authors of this report by agreement with the NRC and SFC. These records and data consisted of the results of annual physical exams during the period August 1986, through June 1988, and included pulmonary function studies, complete blood counts, complete urinalyses, and CHEMSCAN 25 profiles including creatinine clearance. Our review of medical laboratory results covering the period from Janıary 4, 1986, through June 1988, was conducted on urinalys is data obtained from the 31 SFC workers who were suspected of having experienced an acute inhalation exposure to $U_{6}, H F$ and $\mathrm{UO}_{2} \mathrm{~F}_{2}$. Complete data were available for 26 of the workers; partial data were evaluated on the five other workers for whom medical monitoring was discontinued prior to June 1988. No pre-event medical records were provided for comparison with the post-accident information. Hence, it was not possible to evaluate changes from the normal or pre-event values for specific individuals.

Clinical laboratory test data provide the physician with information that may be useful for diagnosing medical problems, but such data do not automatically indicate a definitive diagnosis. Changes in clinical laboratory test values must be compared with previous values for each individual, while aiso taking into account all other physical problems and medical circumstances, before a judgement is made by the physician on the medical significance of the change. Medical experience and judgement are necessary to prevent an inafpropriate interpretation and assignment of cause.

\section{$\underline{\text { FINDINGS }}$}

Analysis of the medical data on SFC workers included review of the urinalysis data, blood tests, kidney function indicators, and pulmonary function tests. These tests are discussed in more detail in the following sections. 


\section{Urinalysis Data}

Eleven workers tested positive for protein (in excess of the normal range) in at least one urine specimen during the first 20 days following the uranium exposure accident

Only one subject (worker E-26) showed positive protein ( $>200 \mathrm{mg} / \mathrm{dL}$ ), glucose $(1-3+)$, and cells (too numerous to count from infection) in the first two samples submitted four days after the accident. This individual was estimated to have received the highest intake of uranium ( $24 \mathrm{mg}$ ) of the 31 workers studied, as well as the highest xidney concentration of uranium $(? .5 \mu \mathrm{g} \mathrm{V} / \mathrm{g}$ tissue). Protein levels, glucose, and cells in urine samples of worker E-26 returned to normal 13 days later, at the time of the next testing. Worker E-26 showed a trace of protein in subsequent samplings through the next nine months. However, this subject also experienced concurrent urinary tract infections (indicated by high bacteria levels and cloudy urine). For the most part, the protein cleared within a day or two.

Urinary tract infections are also often accompanied by protein excretion, and protein excretion associated with infection should not be interpreted as the result of exposure to uranium. The positive finding of protein in urine does not in and of itself prove kidney damage; it is only one indicator of an alteration in tubular function from various causes. Other indicators must also be positive to indicate kidney damage. Based on eview of the clinical urinalysis results, there did not appear to be suffici ant evidence of transitory or long-term kidney damage to worker E-26 (the highest exposed worker) or to any of the other workers as a result of exposure to uranium.

Worker E-12 showed trace protein in urine on day 3 and 8 after the accident, but the test for protein was negative on day 16 and thereafter. Other indicators for nephrotoxicity were similarly negative.

Worker E-23 showed slight positive protein on day 4, and work, E-31 showed slight positive protein on day 6 , but subsequent tests were negative, and other indicators for nephrotoxicity were also negative.

Specific gravity values for all workers remained in the normal range and thus showed no evidence of alteration in the ability of the kidneys of workers to concentrate urine following exposure to uranium. There were also no short-term changes in ability to concentrate urine following the uraniumexposure accident.

Special enzyme tests were also performed on all workers. In addition, three control subjects were evaluated using clinical laboratory tests. In all cases, the results were interpreted as normal.

\section{Blood Tests}

Blood tests included blood urea nitrogen, serum creatinine, total protein, albumin, and the albumin-to-globulin $(A / C)$ ratio. The results of 
these tests remained within normal ranges during the evaluation period for all workers involved in the uranium-exposure accident.

Excessive quantities of amino acids may appear in blood when renal disorders, possibly caused by heavy metal poisoning, are present. 'Creatinine clearance studies on the worker population showed that results remained in the normal range except for one subject (worker E-25), who had a slightly higher-than-expected creatinine level one year after the accident. Worker $E-25$, however, also had minimal exposure to uranium; the estimated intake of uranium by this worker was comparatively low (less than $2 \mathrm{mg} \mathrm{U}$ ), as was his estimated maximum kidney concentration (0.19 $\mu \mathrm{g} \mathrm{V} / \mathrm{g}$ tissue), suggt ing that uranium exposure was not the cause of the elevated creatinine clearance. He was studied for only one year before he changed employers and dropped out of the study.

\section{Kidney Function Tests}

Physiologic urinalyses were not consistently monitored early following the accident, or on a daily basis as would be necessary to detect protein in the urine during the first 5-7 days post-exposure. Protein in the urine would be presumptive evidence of altered tubular function. Thereafter, semimonthly monitoring would be sufficient to monitor poteitial long-term changes in kidney function.

Initiation of exams for protein in urine varied from $\hat{\imath}-21$ days post-event and was not an item checked daily in most cases. No significant changes in kidney function test values were found in the 26 individuals monitored over the two-year follow-up period. CHEMSCAN 25 results and ccmplete blood counts remained essentially unchanged. No abnormal values were noted for any SFC workers, indicating that kidney function in all cases appeared to be unaffected by the accident. Changes could be expected, however, in workers more heavily exposed to soluble uranium than were the SFC employees.

\section{Pulmonary Function}

Pulmonary function studies showed no significant variations over time following the accident--ever. among workers excreting the largest amounts of uranium and who were presumet to be the most heavily exposed to $H F$, $U F_{B}$, and $\mathrm{UO}_{2} \mathrm{~F}_{2}$. Pulmonary testing was performed six months following the cylinder-rupture accident, and then at yearly intervals tiereafter. A more immediate measurement of this parameter after the accident would have been of interest--particularly if these workers were symptomatic during the first few days following exposure. Forced vital capacity did not significantly change for any single worker over the testing period, including one pre-accident measurement. No evidence of significarit or permanen $i$ change was noted for any worker. Of interest to these authors was the fact that pulmonary function test results for many of the workers actually improved, indicating the possibility that test results improved through frequent testing as workers "learned" how to take the test. 
Pulmonary function did not improve for worker E-29, who was already overweight at the time of the accident, and who then gained an additional 15 pounds during the two-year follow-up period of the study. There was no indication, however, of lung damage or lung disease in this worker.

\section{EVALUATIONS OF FUTURE ACCIDENTAL EXPOSURES}

The monitoring frequency for evaluation of medical effects from future accidental exposures to uranium and associated chemical compounds should be tailored to the severity of the accident and the results of initial post-event findings. Follow-up medical data should be compared to pre-event values, and changes should be evaluated with respect to exposure. Factors such as age and change in physical condition should also ise evaluated. observed abnormalities on medicai laboratory tests should be followed, and progress of the patients toward their pre-event (or baseline) values should be expected if permanent damage has not taken place. Baseline values are the normal range values expected for adults (Tables 1 and 2).

Following acute exposure to $\mathrm{UF}_{6}$ and $\mathrm{UO}_{2} \mathrm{~F}_{2}$, daily urine samples should be collected for uranium urinalysis and physiologic analysis (specific gravity, $\mathrm{pH}$, protein, ketones, blood and nitrates, and casts and cells), pulmonary function testing should be performed immediately (if practicable) and monthly thereafter until stability is demonstrated. Dipstick urinalyses are simple to perform, require minimal urine, are inexpensive, and provide immediate indication of protein, pH, specific gravity, glucose, ketones, and blood.

\section{TREATME:T OF EXPOSED WORKERS}

The inhalation of acid fumes with resultant upper respiratory and lung irritation should be treated symptomatically by a medical pulmonologist, if available. Fluoride skin burns over as little as $2.5 \%$ of the body may cause prolongation of the ST-segment [the space between the S-wave and T-wave on an electrocardiogram (ECG)]. This ancmaly, if present, should to be monitored and appropriate treatment instituted by a physician.

The specific treatment of SFC workers was not available to the authors of this report. However, the alkalinity of many urine specimens indicated that sodium bicarbonate was administered to some of the workers, confirming information previously reported (NRC 1986b, pp. 405-406). Alkaline urine increases the dissociation of the uranium bicarbonate complexes and therefore increases excretion of uranium. Frequent tests of urine $\mathrm{pH}$ are necessary to insure that the urine of exposed workers remains alkaline, and to regulate bicarbonate therapy. The use of sodium bicarbonate in physiologic solution ( $14 \%$ in $250 \mathrm{~mL}$, IAEA 1978), orally or by infusion, can be useful for rapidly increasing the urinary excretion of uranium and thus reduce the nephrotoxic effect, and its administration to workers exposed to uranium was recommended by the NCRP in Report 65 (NCRP 1980). The complex formed by uranyl ions with sodium bicarbonate is stable and is excreted quickly from the kidneys into urine. 
Chemical toxicity of the kidney can be treated by dialysis. Chelating agents should not be used for treating exposure to uranium, despite their affinity for uranium, since an increase in the amount transported to the kidneys could lead to uranium precipitation, a high renal tubule burden, and increased potential for nephrotoxicity (IAE4 1978). Chelation therapy should be considered only for serious acute exposures--particularly those involving exposure to enrichment greater than $10 \%$ of ${ }^{236} \mathrm{U}$ to reduce potential radiation exposures. The recommended chelating agent, $\mathrm{CaNa}_{3} \mathrm{DTPA}$, has also not yet received FDA approval for use in uranium expcsure cases; its use on an emergency basis would therefore require special approval of the U.S. Food and Drug Administration prior to administration.

\section{COLLECTION OF COMPLETE URINE DATA}

One of the major problems usually encountered in the analysis of exposure to radioactive materials by workers is the lack of complete data. Following a future accidental exposure to soluble uranium, an effort should be made to collect sufficient urine, as often as possible, to perform clinical tests and uranium analyses. All urine should be collected during the first seven day post-accident. Urine samples not immediately analyzed for uranium should be preserved for later analysis, if needed.

Unfortunately, the present study lacked much data that could have been obtained. Ideally, the total volume of urine for the first week postaccident should be collected and analyzed. In any rase, the daily urinary volume should be recorded, as this is an important basis for determining the total excretion of uranium and other substances. A minimum of $30 \mathrm{~mL}$ is needed to perform simple tests for protein, glucose, specific gravity, and $\mathrm{pH}$. Quantitative protein and glucose testing should be performed if positive dip-stick test results are obtained. A microscopic examination should also be performed on urine sediments by the clinical laboratory. These tests should be repeated from the day of the accident until results are negative or stable. Amino acids, enzymes and beta-2-microglobulin may be obtained by collecting urine and then freezing the samples to $-40^{\circ} \mathrm{C}$ pending laboratory analyses. Blood serum creatinine, creaiinine clearance, and blood urea nitrogen tests are also useful for monitoring kidney glomerular function. 


\section{DOSIMETRIC EVALUATION OF SFC URANIUM BIOASSAY DATA}

Compartmental inodeling teclniques were used to evaluate the SFC bioassay data and to estimate intakes of uranium by workers and subsequent internal doses. Inhaled uranium aerosols deposit in respiratory tract airways or in the alveolar region according to their particle size, mass, and aerodynamic properties. Deposited material is cleared from the lung by dissolution into blood or lymphatic fluids, or by mucociliary clearance according to the chemical form and associcted solubility. Uranium hexafluoride and $\mathrm{UO}_{2} \mathrm{~F}_{2}$ are soluble and are therefore highly transportable from the lung to blood and other extracellular body fluids by abscrption. The transport or "systemic" compartment of the body inciudes blood, lymphatic, and other body fluids. Systemic uranium is fiitered from the blood, concentrated by the kidneys, and excreted in the urine. Uranium circulating in blood through the skeleton may also be deposited on active bone surfaces. Uranium entering the gastrointestinal system from swallowed mucus or from biliary liver clearance is excreted in the feces; however, a fraction of the uranium $(0.2-5 \%$, depending on solubility) is partially reabsorbed from the intestines to the circulatory system. Thus, the kinetics of uranium may be modeled mathematically for dosimetric purposes.

\section{COMPARTMENT MODELS}

Compartment models are mathematical representations of the complex movement of uranium or other materials through the body and are useful for analyzirg intakes, translocation rates, organ uptakes, and excretion rates for dose calculations. We eyaluated two well-regarded compartment models against the SFC Lranium bioassay data to determine which more appropriately fit the data for estimating intake and resulting internal radiation dose. They were 1) the ICRP-30/54 biokinetic mode! (ICRP 1979), and 2) the systemic recycling model proposed by Wrenn, Lipsztein, Bertelli, and Durbin (Wrenn, Lipsztein, and Bertelli 1989; Durbin 1984), which may be used with the ICRP lung, gastrointestinal tract, and organ models (ICRP 1979, 1988; Eve 1966) to predict the deposition, retention, redistribution, and clearance of inhaled uranium compounds. The Wrenn et al. systemic recycling model is receiving increased recognition among radiation protection scientists because it more accurately simulates the recirculation of uranium from organs back into the transfer compartment.

Both biokinetic models are described in the following sections. As a result of comparing and testing these models, we found that a "modified" Wrenn-Lipsztein-Bertelli model most closely fit the SFC bioassay data, and the modified form of this model was therefore used to estimate uranium intake, kidney exposure, and interinal doses to SFC workers for the purposes of this report. 


\section{ICRP BIOKINETIC MODEL (1988)}

The current biokinetic model for radioactive materials, recommended by both the ICRP and the National Council on Radiation Protection and Measurements (NCRP 1985), is described in detail in ICRP Publications 30 (1979) and 54 (1988). As shown in Figure 1, the overall model is comprised of three major parts: 1) a lung model, 2) a gastrointestinal tract model, and 3) a systemic-compartment model that includes bloodstream and other body fluids (the transfer compartment), the kidneys, bone, and all other body tissues.

The ICRP model for retention of internal radionuclides is a "oncethrough" model that assumes first-order kinetics with direct excretion from organs to urine; it does not, generally, identify the pathways of excretion from the body or provide mechanistic feedback to the transfer compartment. It was used to derive limits for air concentrations of radioactivity (DACS) annual limits on intake (ALIs) of radioactive materials by workers, and 50 -year committed effective dose equivalents ( $\mathrm{H}_{50}$ ) per unit intake for radiation protection purposes (ICRP 1979, 1988).

In the ICRP approach, inhaled radioactive materials are categorized as class D (transportable), W (moderately transportable), or Y (slightly transportable) according to their clearance from the pulmonary region with halftimes of days (less than 10 days), weeks (10 to : 70 days), or years (greater than 100 days). Class $D$ soluble uranium, such as $U_{F_{B}}$ is assumed to clear from the lung according to the parameters shown in Table 3 . For the analys is of $U_{F}$ intakes by SFC workers, oniy the class $D$ parameters of the ICRP lung model were used.

The ICRP biokinetic models and radionuclide par nieters are generic models for radiation protection planning, and vilues of Hso calculated using the ICRP-30/54 biokinetic model are based on the metabolic parameters of a Reference Man (ICRP 1975). However, when performing individual dose assessments following arcidents or significant intakes of radioactive materials by workers, the ICRP recommended that age and other known biological parameters, such as specific excretion patterns, be taken into account as far as practicable to individualize the dose assessment (ICRP 1979).

\section{GASTROINTESTINAL TRACT MODEL}

The gastrointestinal trac model of Eve (1966), shown in Figu, e 1, was revised by the ICRP (1979, 108, for derivation of radionuclide exposure limits. The fraction of ura...un. hosorbed from the sinall intestine into the blood stream $\left(f_{1}\right)$ for class ! uranium is assumed to be 0.05 (ICRP 1979, 1988). 


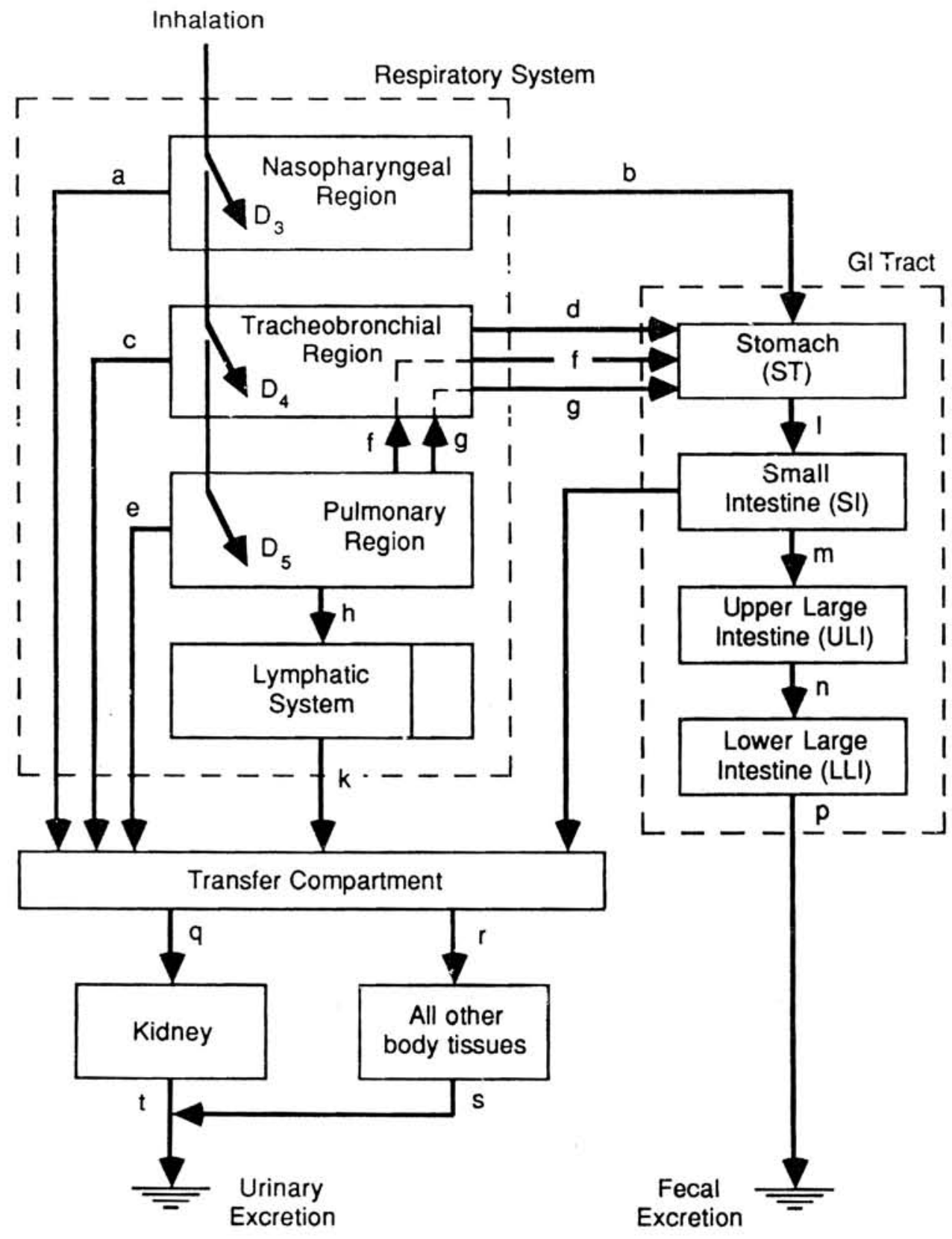

FIGURE 1. ICRP Biokinetic Model (ICRP 1979) 
IABLE 3. Compartmental Fractions ard Clearance Half-times for Class D (transportable) Radioactive Materials (ICRP 1979). Letters in brackets refer to the compartments shown in Figure 1.

\begin{tabular}{|c|c|c|c|}
\hline Compartment & Fraction & $\begin{array}{l}\text { Half-time } \\
\text { (days) }\end{array}$ & Pathway \\
\hline Nasal passage & $\begin{array}{l}0.5 \\
0.5\end{array}$ & $\begin{array}{l}0.01 \\
0.01\end{array}$ & $\begin{array}{l}\text { Body fluids [a] } \\
\text { Gastrointestinal tract [b] }\end{array}$ \\
\hline Tracheobronchial & $\begin{array}{l}0.95 \\
0.05\end{array}$ & $\begin{array}{l}0.01 \\
0.2\end{array}$ & $\begin{array}{l}\text { Body fluids [c] } \\
\text { Gastrointestinal tract [d] }\end{array}$ \\
\hline Pulmonary & $\begin{array}{l}0.8 \\
0.2\end{array}$ & $\begin{array}{l}0.5 \\
0.5\end{array}$ & $\begin{array}{l}\text { Body fluids [e] } \\
\text { Lymphatic tissues [h] }\end{array}$ \\
\hline Lymphatics & 1.0 & 0.5 & Body fluids [k] \\
\hline
\end{tabular}

\section{SYSTEMIC COMPARTMENT MODELS}

A number of different systemic compartment models have been proposed to describe the fate of uranium after it enters the bloodstream (Durbin 1984; ICRP 1979, 1988; Wrenn, Lipsztein, and Bertelli 1989). Two such models were evaluated for this study: the ICRP-30/54 model, and the Wrenn-LipszteinBertelli model.

\section{$\underline{\text { ICRP-30/54 Systemic Model }}$}

The ICRP-30/54 systemic model as applied to class $D$ uranium is shown in Figure 2. In this model, uranium translocates from the transfer compartment with a half-time of 0.25 days. Of the uranium entering the transfer compartment, $12 \%$ and $0.052 \%$ are assumed to translocate to kidneys where it is retained with half-times of 6 and 1500 days, respectively. Twenty percent and $2.3 \%$ translocate to bone to be retained with half-times of 20 and 5000 days. Twelve percent and $0.052 \%$ are assumed to translocate to soft tissues other than the kidneys, where the uranium is retained with half-times of 6 and 1500 days (equation 3 ). The remainder of uranium entering the transfer compartment $(53.6 \%)$ is assumed to go directly to excretion (ICRP 1979, 1938).

The ICRP model assumes that all systemic uranium is excreted in urine, according to the function

$$
\begin{aligned}
y_{u}(t)= & 1.5 \mathrm{e}^{(-0.693 t / 0.25)}+0.028 \mathrm{e}^{(-0.693 \mathrm{t} / 6)}+0.0069 \mathrm{e}^{(-0.693 \div / 20)} \\
& +4.8 \times 10^{-7} \mathrm{e}^{(-0.693 \mathrm{t} / 1500)}+3.2 \times 10^{-6} \mathrm{e}^{(-0.693 \mathrm{t} / 5000)}
\end{aligned}
$$

where $y_{u}(t)$ is the excretion rate at time $t$, and where the denominator in the exponential power is the clearance half-time of each compartment. 


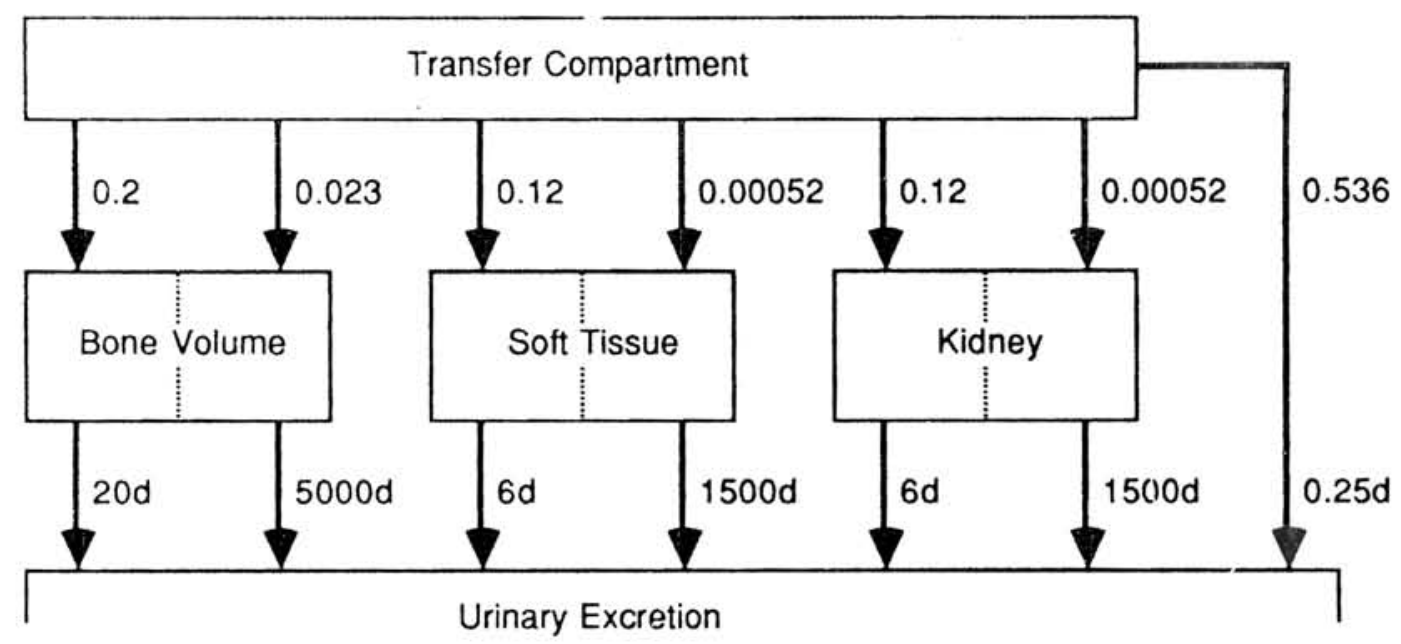

FIGURE 2. ICRP Systemic Model for Uranium

\section{Wrenn-Lipsztein-Bertelli Systemic Model}

Wrenn, Lipsztein, and Bertelli (1988), expanding on previous work by Lipsztein (1981) and Durbin (1984), presented alternative pharmacokinetic models for systemic uranium that included recirculation to blood or plasma from bone volume, soft tissue, red blood cells, and the kidneys. One such recycling model for systemic uranium (Lipsztein 1981, Wrenn et al. 1985, Durbin 1984) is shown in Figure 3 . In this model, the retention half-time of uranium in the kidneys was assumed to be 15 days. Uranium clearing the kidneys was assumed to go directly to urinary excretion.

The Wrenn-Lipsztein-Bertelli model is more physiologically representative of the human than is the ICRP-30/54 systemic model, which assumes direct urinary excretion from bone volume, soft tissue, and the systemic compartment in addition to excretion from the kidneys. The Wrenn-Lipsztein-Bertelli model also predicts a greater early excretion of uranium in urine than does the ICRP model. The amount of uranium remaining in the body after seven days is nearly identical for both models.

Assuming the transfer rate constant from blood to organs corresponds to a half-time of 0.25 days, then the urinary excretion function for the modified Wrenn model is

$$
\begin{aligned}
y_{u}(t)= & 0.86 \mathrm{e}^{-2.77 t}+0.0048 \mathrm{e}^{-0.116 t}+0.00069 \mathrm{e}^{-0.0267 t}+0.00017 \mathrm{e}^{-0.60231 t} \\
& +2.5 \times 10^{-6} \mathrm{e}^{-0.000187 t}
\end{aligned}
$$




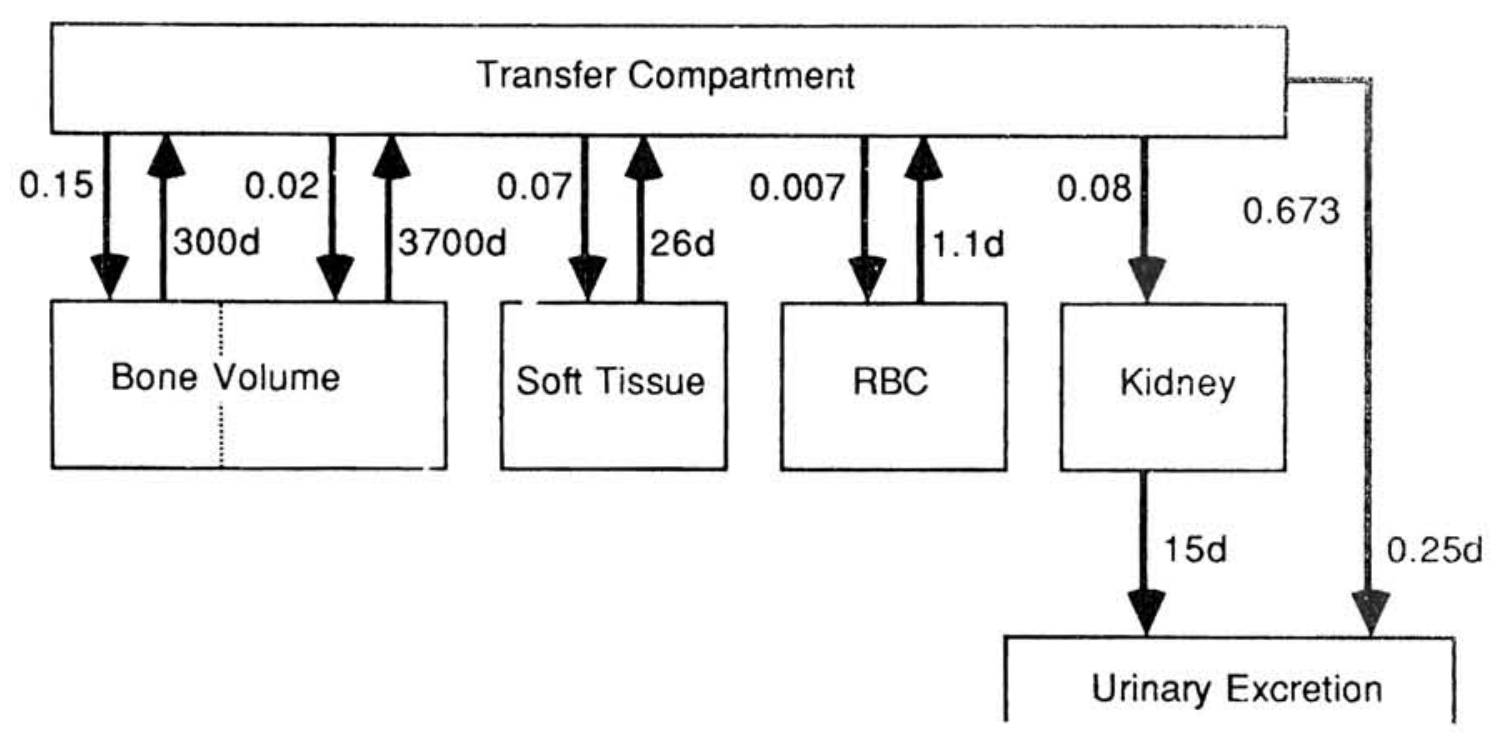

FIGURE 3. The Wrenn-Lipsztein-Bertelli Systemic Model for Uranium

Both the Wrenn-Lipsztein-Bertelli and the ICRP-30/54 systemic models use the ICRP-30/54 lung model (ICRP 1979), Eve's gastrointestinal tract model (Eve 1966), and organ models to evaluate worker exposure to uranium.

\section{METHOD OF DATA ANALYSIS}

Intakes of uranium by SFC workers were evaluated using both the ICRP$30 / 54$ model (ICRP 1979, 1988) and the Wrenn-Lipsztein-Bertelli model (1989, Durbin 1984). Both are featured in a commercial software package for (GENMOD-PC, Atomic Energy of Canada Limited, Chalk River, Ontario, Canada;, which incorporates the ICRP lung model (ICRP 1979), Eve's gastrointestinal model (Eve 1966), and a compartmental organ model. The software also features the Wrenn-Lipsztein-Bertelli uranium recycling model, modified by addition of a liver compartment. The general features of GENMOD-PC were described previously by Dunford and Johnson (1987).

The uranium urinalysis data (in $\mu \mathrm{g} / \mathrm{L}$ ) for each worker were compared to the daily fractional excretion rates predicted by the biokinetic models. We assumed that all workers excreted the Reference Man value of $1.4 \mathrm{~L}$ urine per day (ICRP 1975) so that we could estimate the daily excretion of uranium. The time of intake $(t=0)$ was $11: 30 \mathrm{a} \cdot \mathrm{m}$. on January 4,1986 . We also assumed that the inhaled material consisted of class $D$ natural uranium with an aerosol particle-size distribution of $1.0 \mu \mathrm{m}$ activity median aerodynamic diameter (AMAD). Sensitivity analysis using particle-size diameters other than $1.0 \mu \mathrm{m}$ AMAD showed that neither larger nor smaller diameters provided better fits to the biokinetic models describing uranium excretion than did 
the default choice of $1.0 \mu \mathrm{m}$ AMAD. The specific activity of natural uranium is $0.5866 \mu \mathrm{Ci} / \mathrm{g}$ or $2.543 \times 10^{4} \mathrm{~Bq} / \mathrm{g}$ (without daughter products).

Urinary uranium excretion data were analyzed for each worker and compared to the excretion predicted by the ICRP-30/54 model and the WrennLipsztein-Bertelli model. The excretion data were normalized to estimate intake. The normalized intake by a wcrker, $I_{n}$, was found from

$$
I_{n}=\left(\sum_{i}^{n} A_{i} / G_{i}\right) / n,
$$

where $A_{j}$ is the value of the $i$ th urinalysis at time $t_{j}$ of collection from the worker, for $n$ number of samples, and

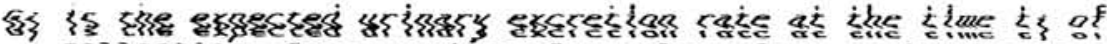

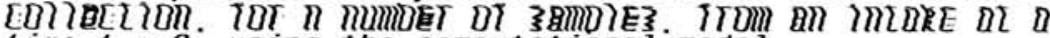

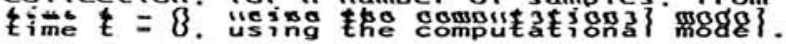

A chi-square statistic $\left(X^{2}\right)$ for the fit of the actual excretion data to the idealized biokinetic model was estimated using the formula

$$
X^{2}=\Sigma_{i}\left[\left(A_{i}-G_{j}\right)^{2} / G_{i}\right]
$$

Our analyses of $X^{2}$ values showed that the excretion data fit the WrennLipsztein-Bertelli recycling model better than the ICRP-30/54 model for class $D$ uranium. The variance of the data from the model showed that further improvements in fit were possible by adjusting some of the model parameters.

\section{REFINEMENT OF THE WRENN-LIPSZTEIN-BERTELLI MODEL}

We minimized the value of $x^{2}$ using the Wrenn-Lipsztein-Bertelli model by careful selection of alternate values for two parameters: the half-time for clearance of uranium from the pulmonary lung compartment, and the half-time for clearance from the kidneys. We found that the $X^{2}$ value was optimized by selecting a retention half-time of 6 days for the clearance of uranium from the kidney to urinary excretion, instead of the 15 days used in the model of Wrenn, Lipsztein, and Berielli (1989), and by selecting a half-time of 0.03 days (approximately 45 minutes) for clearance of uranium from the pulmonary lung to blood, instead of the 0.5 day ( 12 hour) clearance half-time used by the ICRP lung model. This "modified" Wrenn-Lipsztein-Bertelli model was then used to estimate the initial intakes of uranium by workers. We hereafter refer to this model as the modified Wrenn biokinetic model.

\section{COMPARISON OF THE ICRP-30/54 AND MODIFIED WRENN MODELS}

The ICRP-30/54 and modified Wrenn models predict different urinary excreticn rates, lung burdens, and kidney burdens following an acute (single) exposure to soluble uranium. 


\section{Urinary Excretion Rates}

Figure 4 compares the urinary excretion rate (per day) for class $D$ uranium, as a fraction of the initial acute intake, predicted by the ICRP-30/54 model and the modified Wrenn model. The modified Wrenn model predicts a lower daily excretion until about day 80 post-intake.

\section{Clearance of Uranium from Lungs}

Figure 5 shows the retention of class $D$ uranium in the lungs, as a fraction of the initial acute intake, as predicted by the ICRP-30/54 and modified Wrenn models. The short ( 45 minute) clearance half-time from the pulmonary compartment assumed with the modified Wrenn model accounts for the rapid early clearance. Both models predict more than $99 \%$ clearance from the lung by day 5 post-intake.

\section{Uranium Kidney Burdens}

Figure 6 shows the uptake of class $D$ uranium by the kidneys, as a fraction of the initial acute intake, from the ICRP-30/54 and modified Wrenn models. The higher kidney uptake of the ICRP-30/54 model reflects a greater assumed translocation to the kidney $(12 \%)$ than does the modified Wrenn model $(8 \%)$.

\section{Uptake in Bone}

Figure 7 shows the rapid uptake and prolonged retention of class $D$ uraniuin in bone, as a fraction of the initial acute intake, predicted by the ICRP-30/54 and modified Wrenn models. The ICRP-30/54 model predicts a more rapid clearance during the first 90 days post-intake than the modified Wrenn model, which shows a nearly constant retention over the same time period. Bone retention of uranium, according to the modified Wrenn model, decreases by $50 \%$ at about one year post-intake.

\section{SELECTION OF THE MODIFIED WRENN MODEL}

The urinary excretion data for uranium, from ten SFC workers, is plotted in Figure 8 , as a fraction of intake (based on the intake estimate derived from the modified Wrenn model). Each symbol represents a single urine bioassay measurement, and the different symbols each represent a different worker. The modified Wrenn model fit the urinary excretion of class $D$ uranium by SFC workers better than did the ICRP-30/54 model, particularly at early times post-intake, as indicated by the chi-square statistic, evaluated for all workers individually. 


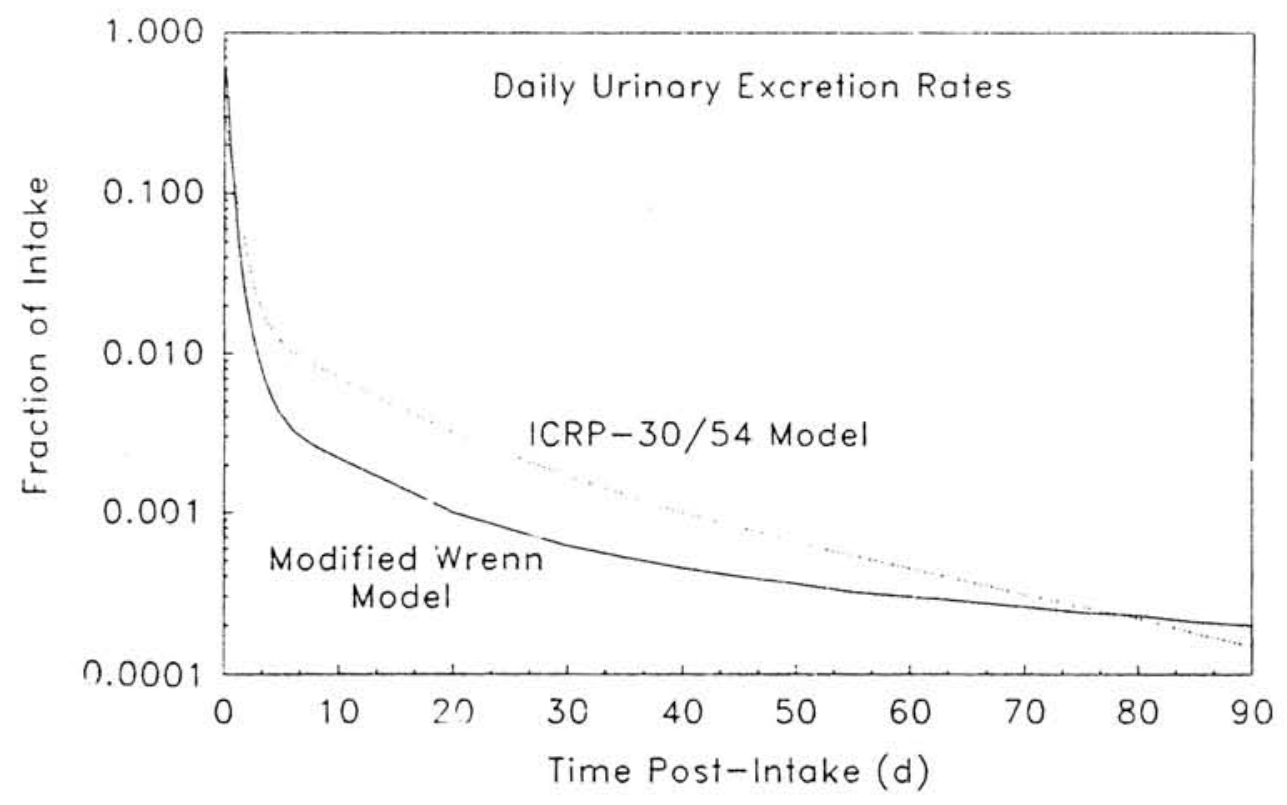

FIGURE 4. Comparison of the ICRP-30/54 and Modified Wrenn Urinary Excretion Functions for Uranium

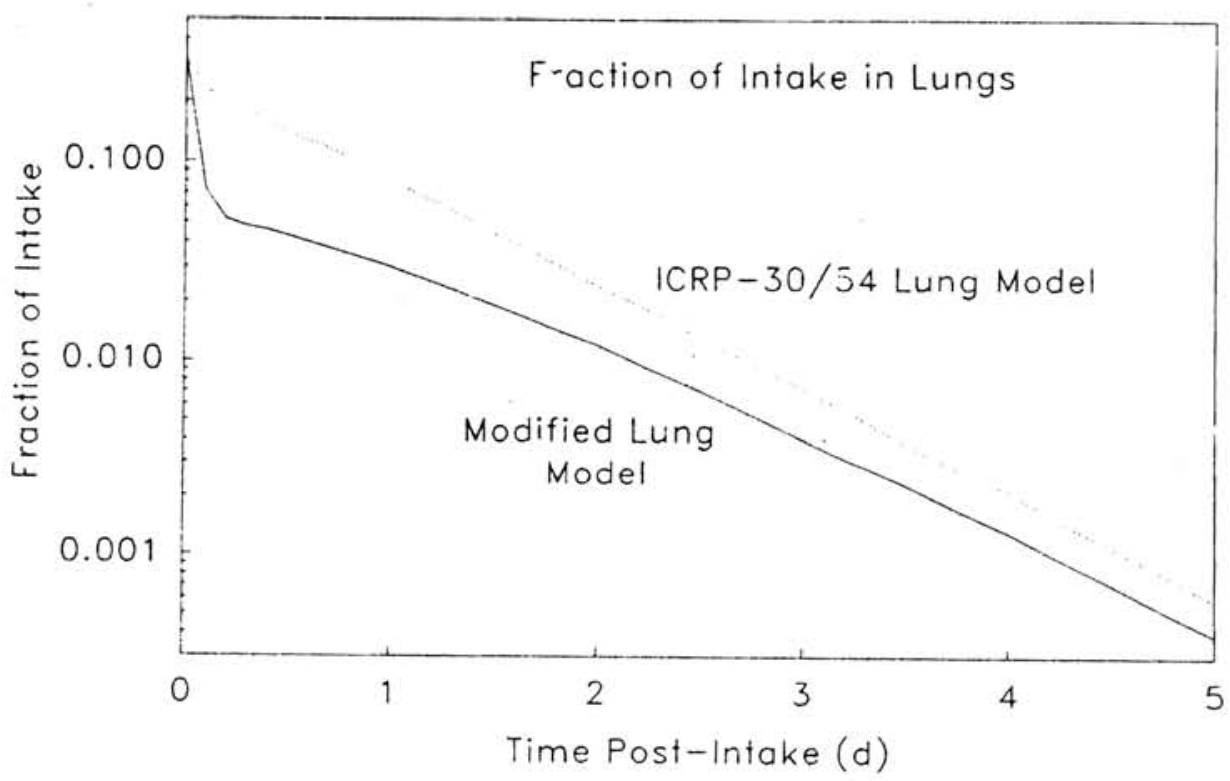

FIGURE 5. Retention of Class D Uranium in the Lungs According to the ICRP-30/54 and Modified Wrenn Models 


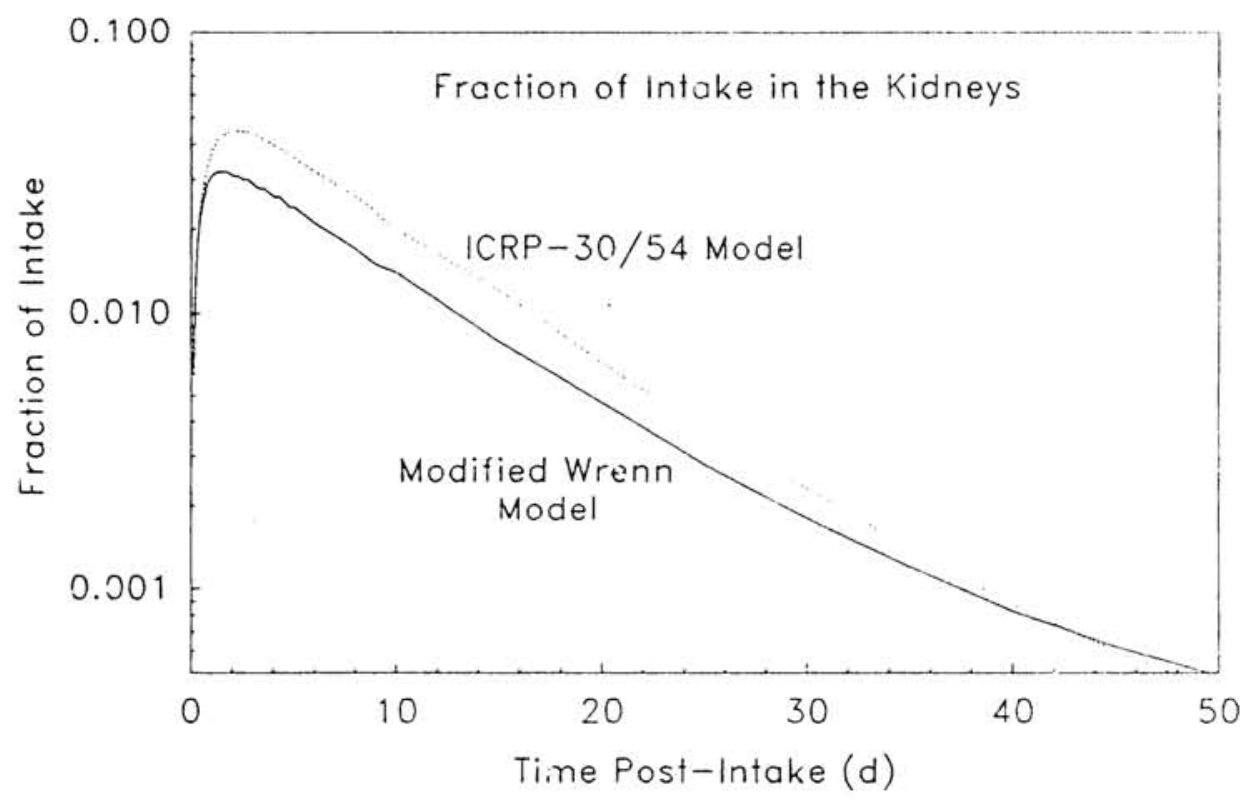

FIGURE 6. Retention of Class D Uranium in the Kidneys According to the ICRP-30/54 and Modified Wrenn Models

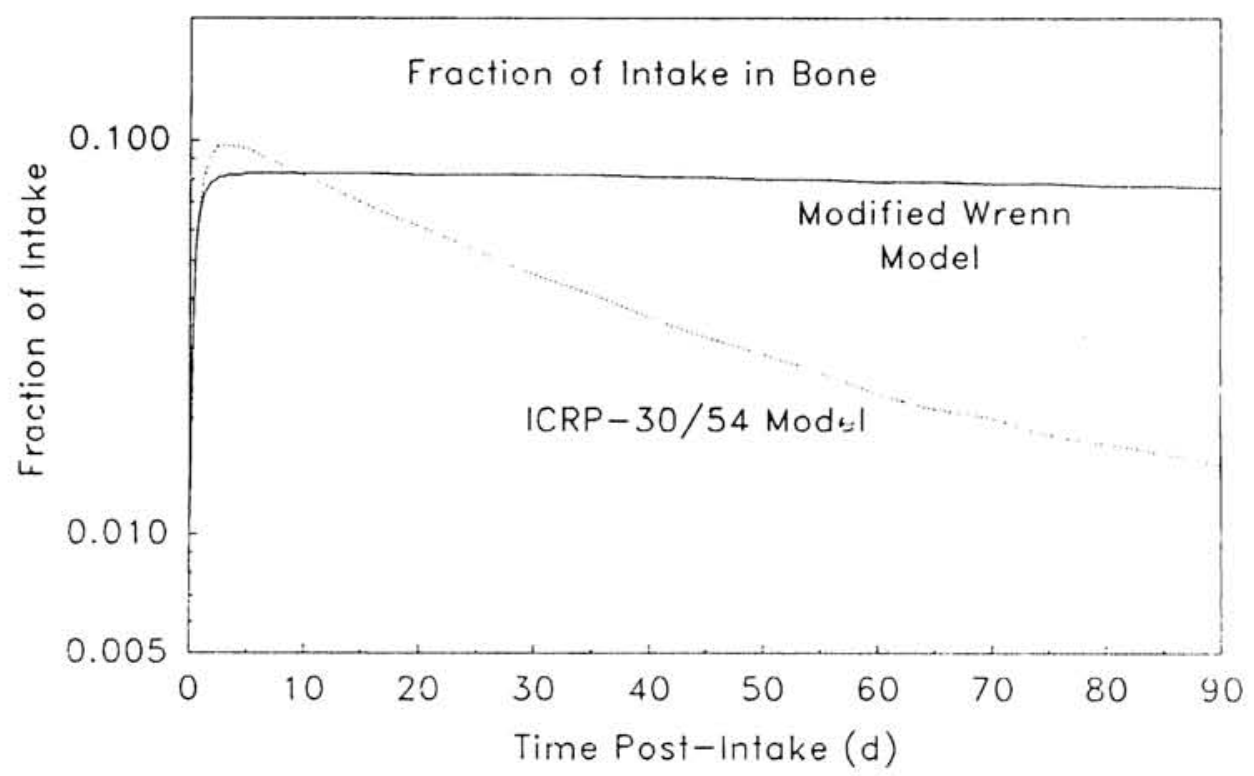

FIGURE 7. Retention of Class D Uranium in Bone According to the ICRP-30/54 and Modified Wrenn Models 


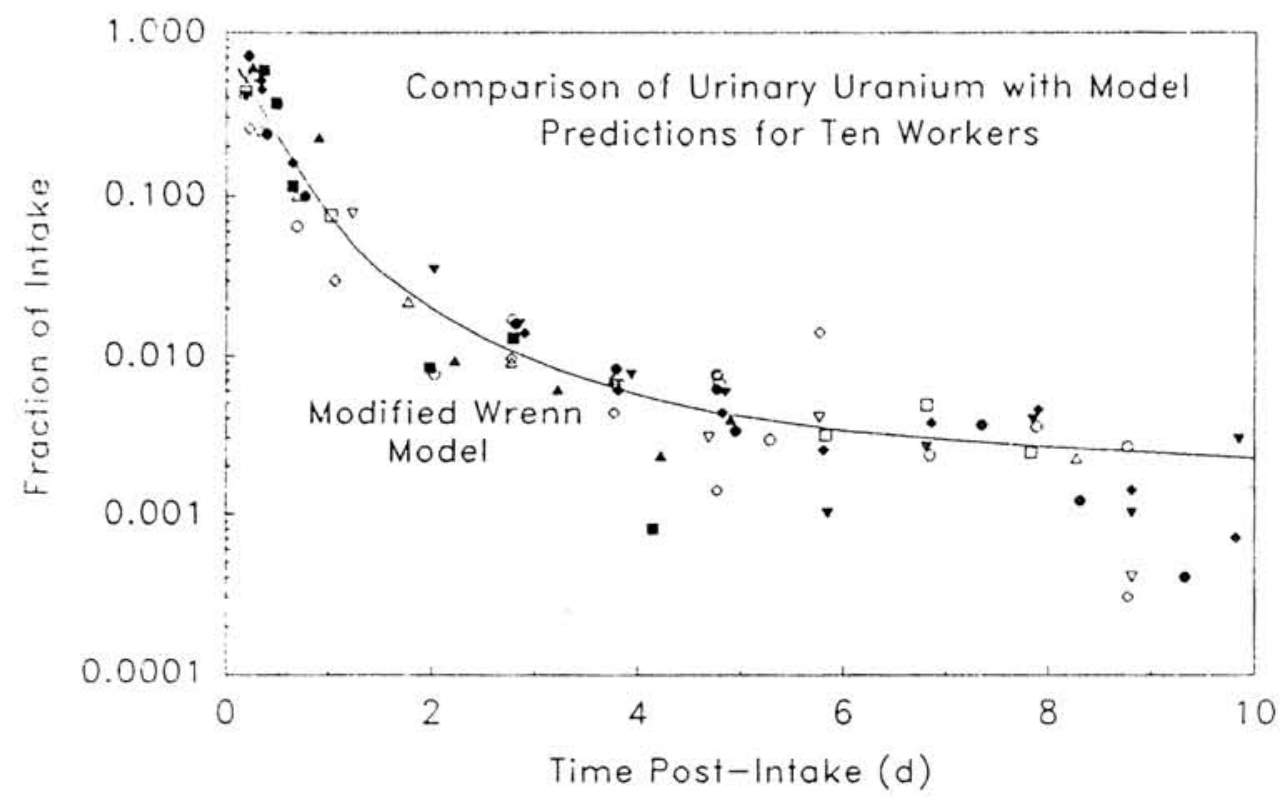

FIGURE 8. Plot of Individual Uranium Urinalysis Measurements, Normalized to the Initial Intake, for Ten SFC Workers

\section{Excretion Function}

The urinary excretion of uranium may be described by an exponential equation of the form

$$
y_{u}(t)=a_{1} e^{-b_{1} t}+a_{2} e^{-b_{2} t}+\ldots+a_{n} e^{-b_{n} t},
$$

where $y_{u}(t)$ is the urinary excretion rate at time $t$ and $b_{n}$ is the coefficient of the equation related to the clearance half-time, such that $b=0.693 / T_{2} \frac{1}{2}$. Each exponential term refers to the clearance from a biological compartment. As described earlier (Equation 4), the excretion function derived from the modified Wrenn model, fitting the curve shown in Figure 8 to a fivecomponent exponential equation, was found to be

$$
\begin{aligned}
y_{-}(i)= & 0.86 \mathrm{e}^{-2.77 t}+0.0048 \mathrm{e}^{-0.118 t}+0.00069 \mathrm{e}^{-0.0267 t}+0.00017 \mathrm{e}^{-0.00231 t} \\
& +2.5 \times 10^{-6} \mathrm{e}^{-0.000187 t}
\end{aligned}
$$

where the half-times of the five components are 0.25 days, 6 days, 26 days, 300 days, and 3700 days $\left(r^{2}=0.996\right)$. A simple power function estimating the urinary excretion (per day) at time $t$ following an intake of class $D$ uranium for times to 2 years post-intake $\left(r^{2}=0.978\right)$ is

$$
y_{u}(t)=0.046 t^{-1.22} \text {. }
$$


The five-component exponential relating directly to the biokinetic model, however, is a better fit to the urinary excretion model than is the simple power function.

\section{DOSIMETRIC ANALYSIS OF SFC WORKER URANIUM URINALYSES DATA}

Uranidm intakes, kidney concentrations of uranium, and resulting radiation doses were estimated from the SFC worker urinalysis data using the modified Wrenn model.

\section{Daily Urinary Excretion Rate}

The measured daily excretion of uranium was compared to the excretion predicted by the modified Wrenn model to estimate the initial intake at time of exposure. The model predicts rapid early clearance of uranium from the lungs and decreasing amounts of uranium in urine over time following a single acute intake by inhalation. According to the modified Wrenn model, the instantaneous fraction of the intake that should be detected in urine is approximately $25 \%$ at 12 hours, $8 \%$ at 24 hours, $2 \%$ at 2 days, $1 \%$ at 3 days, $0.5 \%$ at 4 days, $0.3 \%$ at 10 days, and $0.2 \%$ at 30 days (Figure 4 ).

Uranium urinalysis data were obtained from SFC workers over a two-year period following the cylinder-rupture accident. Since soluble uranium clears very quickly by excretion in urine, it was necessary to determine a point in time for each worker after which the urine bioassay data no longer contributed to a best estimate of the intake. Data for each worker were evaluated individually, and the time point after which data were not used in the intake estimate (usually 10-24 days post intake) was determined arbitrarily and individually for each worker. For example, the urinary excretion rate for worker E-1 is shown in Figure 9 for the time period to 24 days after the accident. Only data points to day 16 were used to estimate the initial intake. After day 16, some of the bioassay measurements showed uranium concentrations below the limit of detection (about $5 \mu \mathrm{g} / \mathrm{L}$, or $7 \mu \mathrm{g} /$ day). Urinary uranium values iess than the detection limit were plotted in Figure 9 just below the dashed line.

Levels of uranium in urine fluctuated near the detection limit after about day 15. It was not clear whether these fluctuations represented measurement error, actual variations in uranium excreted, or continued low-level exposure to uranium by the workers. Erro bars on individual measurement symbols were not included because estimates of the measurenient error were not provided.

Another example is shown in Figure 10, which is a p?ot of the urinary excretion of uranium measured ir samples provided by worker E-23. Also shown in Figure 10 is the urinary excretion rate predicted by the modified Wrenn model (lightly dotted line). This case was typical of several showing rises in urinary excretion of uranium at about 10-15 days post-intake. It was not clear whether this rise in urinary excretion represented clearance of uranium from soft tissues, evidence of new exposure to uranium in the workplace, or random measurement error. 


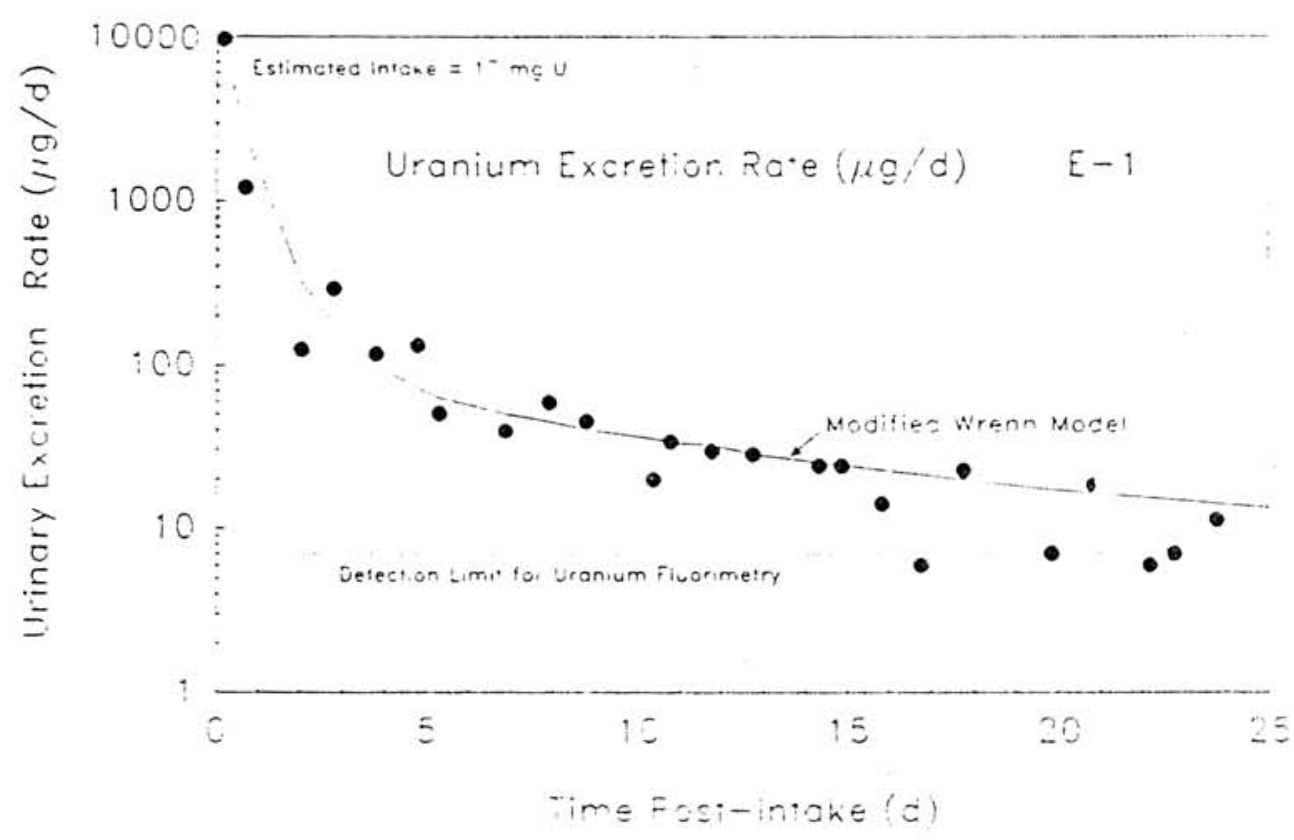

FIGURE 9. Uranium Excretion by SFC Worker E-1

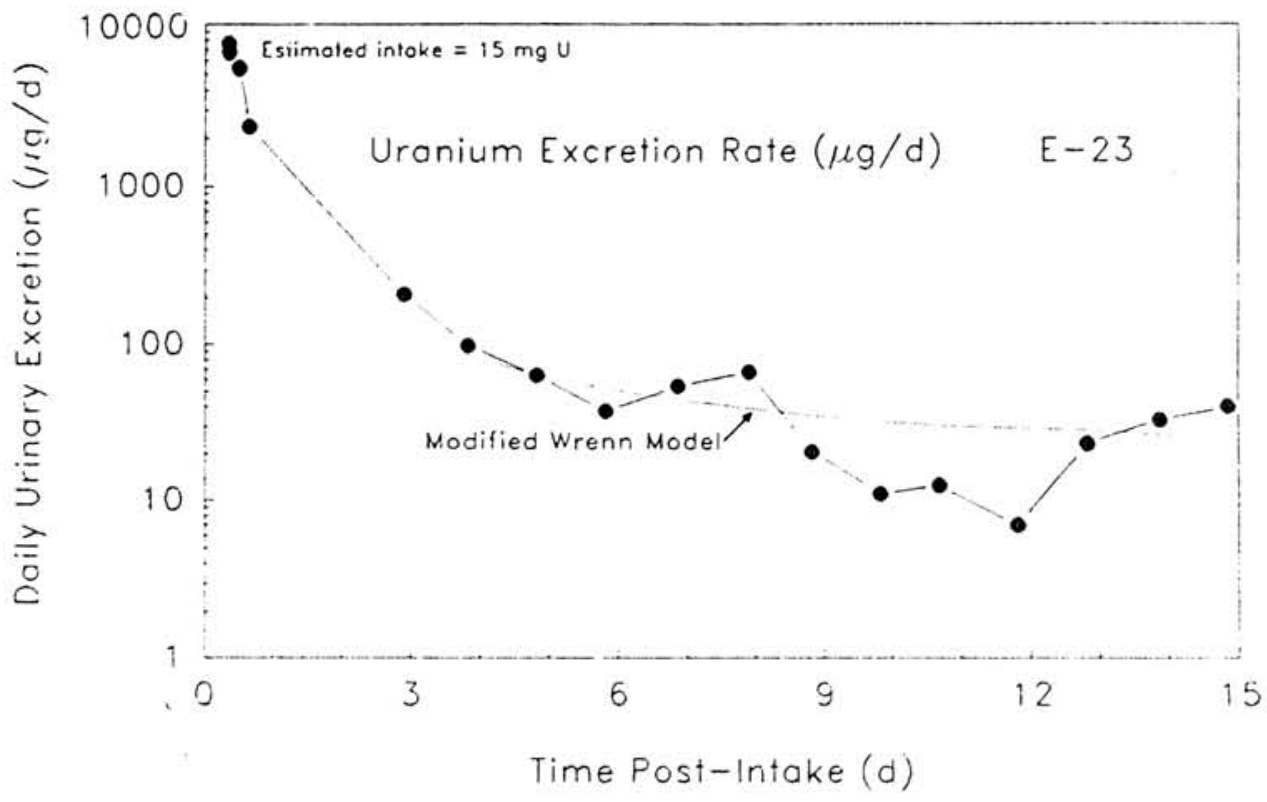

FIGURE 10. Uranium Excretion by SFC Worker E-23 


\section{Estimated Uranium Intakes}

The modified Wrenn model was used to estimate uranium intakes by SFC workers on January 4,1986 . The estimated intakes by workers E-1 and to E-31 are shown in column 2 of Table 4 . The uranium urinalysis data were also used with the model to estimate the committed effective dose equivalent, the maximum kidney concentration, and the long-term integrated kidney retention (columns 3-6 of Table 4).

TABLE 4. Uranium Intakes, Committed Effective Dose Equivalent, Maximum Kidney Concentration, and Long-term Integrated Kidney Retention Est imated for SFC Workers Exposed to $U_{F}$

\begin{tabular}{|c|c|c|c|c|c|}
\hline Worker & $\begin{array}{c}\text { Estimated } \\
\text { Intake } \\
(\mu \mathrm{g}) \\
\end{array}$ & \multicolumn{2}{|c|}{$\begin{array}{c}\text { Committed Effective } \\
\text { Dose Equivalent }\end{array}$} & $\begin{array}{c}\text { Kidney } \\
\text { Concentration } \\
\text { ( } \mu \mathrm{g} / \mathrm{g} \text { tissue) }\end{array}$ & $\begin{array}{l}\text { Kidney } \\
\text { Retention } \\
(\mu \mathrm{g} \bullet \mathrm{d})\end{array}$ \\
\hline$E-1$ & 17,000 & $3.3 \mathrm{E}-4$ & 33.0 & 1.8 & 7,500 \\
\hline$E-2$ & 11,000 & $2.2 \mathrm{E}-4$ & 22.0 & 1.1 & 4,800 \\
\hline$E-3$ & 5,000 & $1.0 \mathrm{E}-4$ & 10.0 & 0.51 & 2,200 \\
\hline$E-5$ & 18,000 & $3.8 \mathrm{E}-4$ & 38.0 & 1.9 & 7,900 \\
\hline$E-6$ & 4,200 & $8.4 E-5$ & 8.4 & 0.43 & 1,800 \\
\hline$E-7$ & 5,800 & $1.2 \mathrm{E}-4$ & 12.0 & 0.60 & 2,600 \\
\hline$E-8$ & 1,300 & $2.5 \mathrm{E}-5$ & 2.5 & 0.13 & 570 \\
\hline$E-9$ & 12,000 & $2.5 \mathrm{E}-4$ & 25.0 & 1.2 & 5,300 \\
\hline$E-10$ & 2,300 & $4.6 \mathrm{E}-5$ & 4.6 & 0.24 & 1,000 \\
\hline$E-11$ & 1,700 & $3.6 \mathrm{E}-5$ & 3.6 & 0.18 & 750 \\
\hline E-12 & 8,400 & $1.7 \mathrm{E}-4$ & 17.0 & 0.87 & 3,700 \\
\hline$E-13$ & 4,300 & $8.9 E-5$ & 8.9 & 0.44 & 1,900 \\
\hline$E-14$ & 5,600 & $1.1 \mathrm{E}-4$ & 11.0 & 0.58 & 2,500 \\
\hline E-15 & 1,500 & $3.0 \mathrm{E}-5$ & 3.0 & 0.15 & 660 \\
\hline$E \cdots 16$ & 6,000 & $1.2 \mathrm{E}-4$ & 12.0 & 0.62 & 2,600 \\
\hline$E-17$ & 18,000 & $3.8 \mathrm{E}-4$ & 38.0 & 1.9 & 7,900 \\
\hline E-18 & 11,000 & 2. $2 \mathrm{E}-4$ & 22.0 & 1.1 & 4,800 \\
\hline E-19 & 3,000 & $6.1 \mathrm{E}-5$ & 6.1 & 0.31 & 1,300 \\
\hline$E-20$ & 3,300 & $6.9 \mathrm{E}-5$ & 6.9 & 0.34 & 1,500 \\
\hline$E-21$ & 630 & $1.3 \mathrm{E}-5$ & 1.3 & 0.065 & 280 \\
\hline$E-22$ & 2,800 & $5.8 \mathrm{E}-5$ & 5.8 & 0.29 & 1,200 \\
\hline$E-23$ & 15,000 & $3.0 \mathrm{E}-4$ & 30.0 & 1.5 & 6,600 \\
\hline$E-24$ & 470 & $9.4 \mathrm{E}-6$ & 0.94 & 0.048 & 210 \\
\hline$E-25$ & 1,800 & $3.6 \mathrm{E}-5$ & 3.6 & 0.19 & 790 \\
\hline$E-26$ & 24,000 & $4.8 \mathrm{E}-4$ & 48.0 & 2.5 & 10,600 \\
\hline$E-27$ & 6,000 & $1.2 \mathrm{E}-4$ & 12.0 & 0.62 & 2,600 \\
\hline$E-28$ & 2,600 & $5.3 \mathrm{E}-5$ & 5.3 & 0.27 & 1,100 \\
\hline$E-29$ & 7,400 & $1.5 \mathrm{E}-4$ & 15.0 & 0.76 & 3,300 \\
\hline$E-30$ & 1,900 & $3.8 \mathrm{E}-5$ & 3.8 & 0.20 & 840 \\
\hline$E-31$ & 8,700 & $1.8 \mathrm{E}-4$ & 18.0 & 0.90 & 3,800 \\
\hline
\end{tabular}


Estimates of initial uranium intake by SFC workers ranged from 470 to $24,000 \mu \mathrm{g}(0.47-24 \mathrm{mg} U)$. The annual limit on intake (ALI) set by the ICRP for class D uranium, derived from Publication 30 (ICRP 1979), is approximately $2,000 \mathrm{mg} U(2.0 \mathrm{~g} \mathrm{U})$; however, this limit was based only on radiation dose--but not the chemical toxicity of urar in the body (ICRP 1979). The specific activity of natural uranium is $25 \mathrm{kig} / \mathrm{g}(675 \mathrm{nCi} / \mathrm{g})$; therefore $2,000 \mathrm{mg}$ natural uranium is equivalent to $50 \mathrm{kBq}(1.35 \mu \mathrm{Ci})$. None of the SFC workers exceeded the intake limit established by the ICRP for class D natural uranium.

The American Conference of Governmental Industrial Hygienists (ACGIH) adopted the recommendations of the NCRP for limiting exposures to ionizing radioactive materials, but published separate threshold limit values (TLVS) for chemical substances. The TLV for soluble and insoluble uranium, based on the chemical toxicity of uranium and time-weighted exposure averages (TWA), is $0.2 \mathrm{mg} \mathrm{U} / \mathrm{m}^{3}$ air in the workplace (ACGIH 1986, 1988). The NRC deriver! intake limit, based on permissible concentrations of soluble natural uranium in air, was obtained from the ACGIH TLV of $0.2 \mathrm{mg} \mathrm{U} / \mathrm{m}^{3}$ air (U.S. Code 1989), as follows:

$$
\begin{aligned}
& 0.2 \mathrm{mg} \mathrm{U} / \mathrm{m}^{3} * 1 \mathrm{~m}^{3} / 1000 \mathrm{~L} * 20 \mathrm{~L} / \mathrm{min} * 60 \mathrm{~min} / \text { hour } * 40 \text { hours } / \text { week } \\
& =9.6 \mathrm{mg} \mathrm{U},
\end{aligned}
$$

where the assumed breathing rate for light-activity work was assumed to be $20 \mathrm{~L} / \mathrm{min}$. This NRC short-term, derived intake limit of $9.6 \mathrm{mg} \mathrm{U}$ was exceeded by eight of the 31 SFC workers according to the intake estimates in this report (Tables 4 and 5 ).

The ACGIH TLV and NRC concentration limits may be compared with recommendations adopted in other countries for airborne uranium: Buigaria, Poland, and the Soviet Union $\left(0.075 \mathrm{mg} \mathrm{U} / \mathrm{m}^{3}\right.$ insoluble compounds and $0.015 \mathrm{mg} \mathrm{U} / \mathrm{m}^{3}$ soluble compounds); West Germany, Switzerland and Yugoslavia $\left(0.25 \mathrm{mg} \mathrm{U} / \mathrm{m}^{3}\right.$ insoluble, and $0.05 \mathrm{mg} \mathrm{U} / \mathrm{m}^{3}$ soluble); Belgium, Finland, and the Netherlands $\left(0.2 \mathrm{mg} \mathrm{U} / \mathrm{m}^{3}\right.$ for soluble compounds only); and Australia $\left(0.2 \mathrm{mg} \mathrm{U} / \mathrm{m}^{3}\right.$ for both soluble and insoluble compounds of uranium) (ACGIH 1988).

Estimates of intake calculated for this report, using complete bioassay data, differ somewhat from the preliminary estimates given by the NRC in NUREG-1189, Vol. 2 (NRC 1986), which were the averaged of the BNL, PNL, and ORNL estimates from early bioassay results (partial data). The ICRP-30 biokinetic model was the basis for the BNL, PNL, and ORNL calculations. A comparison of the average estimates in NUREG-1189 with estimates in this report is shown in Tabie 5 .

\section{Committed Effective Dose Equivalent}

The committed effective dose equivalent is the sum of the committed dose equivalents to various tissues in the body, each multiplied by its weighting factor (ICRP 1977, 1979). The committed óose equivalent is the dose equivalent projected to be received by a tissue or organ over a 50-year period 
TABLE 5. Comparison of Uran ium Intakes $(\mu \mathrm{g})$ Estimated for SFC Workers in (NRC 1986a), with Intake Estimates in Table 4 of this Report

\begin{tabular}{|c|c|c|c|c|c|}
\hline Worker & NUREG-1189 & This Report & Worker & NUREG-1189 & This Report \\
\hline $\begin{array}{l}E-1 \\
E-2 \\
E-3 \\
E-4 \\
E-5 \\
E-6 \\
E-7 \\
E-8 \\
E-9 \\
E-10 \\
E-11 \\
E-12 \\
E-13 \\
E-14 \\
E-15 \\
E-16\end{array}$ & $\begin{array}{r}13,000 \\
20,170 \\
3,630 \\
450 \\
20,870 \\
6,640 \\
12,030 \\
1,340 \\
6,350 \\
\star \star \\
1,600 \\
6,790 \\
2,370 \\
7,190 \\
1,180 \\
12,470\end{array}$ & $\begin{array}{r}17,000 \\
11,000 \\
5,000 \\
\star \\
18,000 \\
4,200 \\
5,800 \\
1,300 \\
12,000 \\
2,300 \\
1,700 \\
8,400 \\
4,300 \\
5,600 \\
1,500 \\
6,000\end{array}$ & $\begin{array}{l}E-17 \\
E-18 \\
E-19 \\
E-20 \\
E-21 \\
E-22 \\
E-23 \\
E-24 \\
E-25 \\
E-26 \\
E-27 \\
E-28 \\
E-29 \\
E-30 \\
E-31\end{array}$ & $\begin{array}{r}27,630 \\
8,330 \\
1,360 \\
1,540 \\
260 \\
1,720 \\
21,330 \\
450 \\
3,630 \\
10,360 \\
5,920 \\
3,180 \\
19,200 \\
730 \\
3,660\end{array}$ & $\begin{array}{r}18,000 \\
11,000 \\
3,000 \\
3,300 \\
630 \\
2,800 \\
15,000 \\
470 \\
1,800 \\
24,000 \\
6,000 \\
2,600 \\
7,400 \\
1,900 \\
8,700\end{array}$ \\
\hline
\end{tabular}

* Insufficient data for analysis

$\star \star$ Not given

following an intake of radioactive material; it does not include contributions to the dose from external penetrating radiations. Committed effective dose equivalent is expressed in units of sievert (1 Sv $=100 \mathrm{rem}$ ).

Estimates of the committed effective dose equivalent for SFC workers from $U F_{B}$ inhaled at the time of the accident ranged from 10-480 $\mu \mathrm{SV}$ ( 1 to $48 \mathrm{mrem}$ ) (Table 4). The annual limit recommended for workers by the ICRP is $50 \mathrm{mSv}$ (5 rem) (ICRP 1977). These analyses showed that neither the stochastic nor the nonstochastic annual limits on intake (ALI) for uranium, recommended by the International Commission on Radiological Protection (ICRP 1979) were exceeded, and that the calculated committed effective dose equivalents for workers were much less than non-stochastic exposure limit of $0.5 \mathrm{~Sv}$ (50 rem) to all tissues and the stochastic limit of $0.05 \mathrm{~Sv}$ (5 rem) to the whole body for internal emitters (ICRP 1979).

\section{Maximum Kidney Concentration}

Uranium concentrations in the kidneys are variable following an intake of uranium. Estimates of the maximum kidney concentrations in SFC workers following the accident ranged from 0.048-2.5 $\mu \mathrm{g} \mathrm{U} / \mathrm{g}$ tissue (Table 4). The accidental exposure was short-term, or "acute," rather than long-term, lowlevel "chronic." Even so, the concentration in kidneys following an acute intake may be sistained over a period of many days due to recycling of uranium from organs and tissues back into blood (the transfer compartment) and due to prolonged retention of uranium deposited in kidney tissue. Under 
such circumstances, the recommended maximum kidney concentration given by different scientists of $1-3 \mu \mathrm{g} \mathrm{V} / \mathrm{g}$ tissue applies to both acute and chronic intakes.

As previously stated, there were no toxic effects attributable to uranium observed in the clinical data of the worker with the highest estimated intake $(E-26)$. The accelerated clearance of uranium following administration of sodium bicarbonate may have protected the kidneys from greater uranium uptakes, long retention times, and tissue damage. We concluded from these data that there was no evidence of nephrotoxicity following the acute inhalation exposure to class $D U_{B}$ that resulted in a maximum concentration of uranium in the kidneys of $2.5 \mu \mathrm{g} \mathrm{V} / \mathrm{g}$ tissue. It was not possible from these data to estimate the threshold kidney concentration for nephrotoxicity in humans, presumably because that threshold is greater than $2.5 \mu \mathrm{g} \mathrm{U} / \mathrm{g}$ tissue.

Experimental data on humans exposed to high levels of uranium for brief periods or injected deliberately with uranium to study the toxicity of acute uranium exposures have shown that kidney concentrations exceeding $3 \mu \mathrm{g} / \mathrm{g}$ tissue or higher can be tolerated without significant, long-lasting damage to the kidneys (Leggett 1989).

\section{Long-Term Integrated Kidney Retention}

The integrated kidney retention is the product of the amount of uranium and time the uranium is retained in the kidneys. We estimated that the integrated retention of uranium in kidneys ranged from 210-10,600 $\mu \mathrm{g}$-days of tissue exposure (Table 4). We concluded from these data that there was no evidence of nephrotoxicity for kidney exposures within this range. The threshold kidney exposure for nephrotoxicity could not be estimated from these results.

\section{Estimates of Dose Equivalent to Tissues}

The dose equivalent is the product of the absorbed radiation dose in tissue, a quality factor comparing the biological effectiveness of different radiation qualities, and other modifying factors (ICRP 1977). Dose equivalent is expressed in sieverts ( $1 \mathrm{~Sv}=100 \mathrm{rem})$. The estimated dose equivalents to bone surfaces, kidneys, and lungs of each worker are shown in Table 6. The nonstochastic exposure limit of $0.5 \mathrm{~Sv}$ (50 rem) to any tissue (ICRP 1979) was not exceeded for any SFC worker.

\section{Chest Count Measurement Results}

A mobile in vivo counting laboratory was sent to 0klahoma to measure uranium iing burdens in SFC workers involved in the accident. Resulcs of these measuremerts, obtained on January 17-22, 1986, are shown in Table 7. Since the reeusurements were made 13-18 days after exposure to $U_{B}$, most of the inhaled uranium was likely to have cleared prior to chest-counting.

Chest counts for worker E-26 (estimated to have received the greatest intake of uranium at the time of the accident) were not significantly different from the results obtained for any other worker. We concluded that 
TABLE 6. Estimated Organ Dose Equivalent (Sv) for SFC Workers from the Accidental Intake of $U_{B}$

\begin{tabular}{|c|c|c|c|}
\hline Worker & Bone Surfaces & Kidneys & Lungs \\
\hline$E-1$ & $6.0 E-3$ & $7.3 E-4$ & $4.3 E-5$ \\
\hline$E-2$ & $3.9 \mathrm{E}-3$ & $4.8 \mathrm{E}-4$ & $2.8 \mathrm{E}-5$ \\
\hline$E-3$ & $1.8 \mathrm{E}-3$ & 2. $2 \mathrm{E}-4$ & $1.3 \mathrm{E}-5$ \\
\hline$E-5$ & $6.4 \mathrm{E}-3$ & $7.8 \mathrm{E}-4$ & $4.6 \mathrm{E}-5$ \\
\hline$E-6$ & 1. $5 \mathrm{E}-3$ & $1.8 \mathrm{E}-4$ & $1.1 \mathrm{E}-5$ \\
\hline$E-7$ & $2.1 \mathrm{E}-3$ & $2.5 \mathrm{E}-4$ & $1.5 \mathrm{E}-5$ \\
\hline$E-8$ & $4.6 \mathrm{E}-4$ & $5.6 \mathrm{E}-5$ & $3.3 \mathrm{E}-6$ \\
\hline$E-9$ & $4.3 \mathrm{E}-3$ & $5.2 \mathrm{E}-4$ & $3.0 \mathrm{E}-5$ \\
\hline$E-10$ & $8.2 \mathrm{E}-4$ & $9.9 \mathrm{E}-5$ & $5.8 \mathrm{E}-6$ \\
\hline$E-11$ & $6.0 \mathrm{E}-4$ & $7.3 E-5$ & $4.3 E-6$ \\
\hline$E-12$ & $3.0 \mathrm{E}-3$ & $3.6 \mathrm{E}-4$ & $2.1 \mathrm{E}-5$ \\
\hline$E-13$ & $1.5 \mathrm{E}-3$ & 1. $9 \mathrm{E}-4$ & $1.1 \mathrm{E}-5$ \\
\hline$E-14$ & 2.0E-3 & $2.4 \mathrm{E}-4$ & $1.4 \mathrm{E}-5$ \\
\hline$E-15$ & $5.3 \mathrm{E}-4$ & $6.5 \mathrm{E}-5$ & $3.8 \mathrm{E}-6$ \\
\hline$E-16$ & $2.1 \mathrm{E}-3$ & $2.6 \mathrm{E}-4$ & $1.5 \mathrm{E}-5$ \\
\hline$E-17$ & $6.4 E-3$ & $7.8 E-4$ & $4.6 \mathrm{E}-5$ \\
\hline$E-18$ & $3.9 \mathrm{E}-3$ & $4.7 \mathrm{E}-4$ & $2.8 \mathrm{E}-5$ \\
\hline$E-19$ & $1.1 \mathrm{E}-3$ & $1.3 \mathrm{E}-4$ & $7.6 \mathrm{E}-6$ \\
\hline$E-20$ & $1.2 \mathrm{E}-3$ & $1.4 \mathrm{E}-4$ & $8.4 \mathrm{E}-6$ \\
\hline $\mathrm{E}-21$ & $2.2 \mathrm{E}-4$ & $2.7 \mathrm{E}-5$ & $1.6 \mathrm{E}-6$ \\
\hline$E-22$ & $1.0 \mathrm{E}-3$ & 1. $2 \mathrm{E}-4$ & $7.1 \mathrm{E}-6$ \\
\hline$E-23$ & $5.3 \mathrm{E}-3$ & $6.5 \mathrm{E}-4$ & $3.8 \mathrm{E}-6$ \\
\hline $\mathrm{E}-24$ & $1.7 \mathrm{E}-4$ & $2.0 \mathrm{E}-5$ & $1.2 \mathrm{E}-6$ \\
\hline$E-25$ & $6.4 \mathrm{E}-4$ & $7.8 \mathrm{E}-5$ & 4. $6 \mathrm{E}-6$ \\
\hline$E-26$ & $8.5 E-3$ & 1.0E-3 & $6.1 \mathrm{E}-5$ \\
\hline$E-27$ & $2.1 \mathrm{E}-3$ & 2. $6 \mathrm{E}-4$ & $1.5 \mathrm{E}-5$ \\
\hline$E-28$ & $9.2 \mathrm{E}-4$ & $1.1 \mathrm{E}-4$ & $6.6 \mathrm{E}-6$ \\
\hline$E-29$ & $2.6 \mathrm{E}-3$ & $3.2 \mathrm{E}-4$ & $1.9 \mathrm{E}-5$ \\
\hline$E-30$ & $6.8 \mathrm{E}-4$ & $8.2 E-5$ & $4.8 \mathrm{E}-6$ \\
\hline$E-31$ & $3.1 \mathrm{E}-3$ & $3.8 \mathrm{E}-4$ & 2. $2 \mathrm{E}-5$ \\
\hline
\end{tabular}

these data do not provide useful dosimetric information, and therefore the data were not used for any of the analyses presented in this report; they were included only for completeness. The one positive value for ${ }^{235} U$ measured in the chest count of worker E-27 (Table 7) did not correlate with that worker's estimate of intake or lung burden, and may possibly represent a false-positive measurement. 
TABLE 7. Results of In Vivo Chest-count Measurements(a)

\begin{tabular}{|c|c|c|c|}
\hline Worker & $\begin{array}{c}\text { Natural } \\
\text { Uranium (nCi) }\end{array}$ & $\begin{array}{c}{ }^{235} \mathrm{U} \\
(\mu \mathrm{g})\end{array}$ & $\begin{array}{c}\text { Date } \\
\text { Counted }\end{array}$ \\
\hline$E-1$ & $2.2 \div 1.1$ & $0 \neq 33$ & $1 / 17 / 86$ \\
\hline$E-2$ & $2.5 \neq 1.3$ & $0 \pm 44$ & $1 / 17 / 86$ \\
\hline$E-3$ & $3.4 \pm 1.5$ & $0 \pm 43$ & $1 / 17 / 86$ \\
\hline$E-4$ & $3.0 \neq 1.2$ & $0 \pm 41$ & $1 / 17 / 86$ \\
\hline$E-5$ & $4.7 \neq 1.5$ & $0 \neq 40$ & $1 / 20 / 86$ \\
\hline$E-6$ & $2.5 \neq 1.3$ & $0=40$ & $1 / 17 / 86$ \\
\hline$E-7$ & $2.8 * 1.1$ & $0 \neq 34$ & $1 / 17 / 86$ \\
\hline$E-8$ & $2.4 \div 1.1$ & $0 \pm 40$ & $1 / 20 / 86$ \\
\hline$E-9$ & $2.3 \pm 1.0$ & $0 \pm 27$ & $1 / 17 / 86$ \\
\hline$E-10$ & $2.3 \pm 1.1$ & $0 \neq 28$ & $1 / 17 / 86$ \\
\hline$E-11$ & $2.3 \pm 1.1$ & $0 \pm 33$ & $1 / 17 / 86$ \\
\hline$E-12$ & $2.5 \pm 1.4$ & $0 \neq 41$ & $1 / 17 / 86$ \\
\hline$E-13$ & $3.1=1.0$ & $0=30$ & $1 / 20 / 86$ \\
\hline$E-14$ & $2.3 \pm 1.3$ & $0 \neq 34$ & $1 / 22 / 86$ \\
\hline$E-15$ & $2.8 \pm 1.4$ & $0 \pm 42$ & $1 / 21 / 86$ \\
\hline$E-16$ & $2.1 \pm 1.3$ & $0 \pm 38$ & $1 / 17 / 86$ \\
\hline$E-17$ & $3.8 \neq 1.3$ & $0 \pm 38$ & $1 / 17 / 86$ \\
\hline$E-18$ & $2.6 \pm 1.2$ & $0 \pm 37$ & $1 / 17 / 86$ \\
\hline$E-19$ & $4.5 \pm 1.4$ & $0 \pm 49$ & $1 / 17 / 86$ \\
\hline$E-20$ & $3.8 * 1.3$ & $0 \pm 42$ & $1 / 17 / 86$ \\
\hline$E-21$ & $5.0 \pm 1.3$ & $0 \pm 37$ & $1 / 21 / 86$ \\
\hline$E-22$ & $3.7 \pm 1.3$ & $0 \pm 41$ & $1 / 17 / 86$ \\
\hline$E-23$ & $0.0=1.3$ & $0 \neq 44$ & $1 / 17 / 86$ \\
\hline$E-24$ & (no data & provided) & \\
\hline$E-25$ & (no data & provided) & \\
\hline$E-26$ & $2.3 \div 1.4$ & $0 \neq 48$ & $1 / 20 / 86$ \\
\hline$E-27$ & $3.4 \pm 1.3$ & $46 * 38$ & $1 / 22 / 86$ \\
\hline$E-28$ & $2.7 \pm 1.5$ & $0 \neq 48$ & $1 / 21 / 86$ \\
\hline$E-29$ & $5.6 \pm 1.4$ & $0 \neq 38$ & $1 / 20 / 86$ \\
\hline$E-30$ & $2.5 \pm 1.0$ & $0 \pm 31$ & $1 / 21 / 86$ \\
\hline & $2.3 \pm 1.1$ & $0 \pm 31$ & $1 / 20 / 86$ \\
\hline
\end{tabular}

(a) "0" indicates a measurement result less than the minimum detectable activity. 


\section{CONCLUSIONS}

The uranium urinalysis data on $31 \mathrm{SFC}$ workers exposed to soluble $\mathrm{UF}_{6}$ and its hydrolysis products provided new information on the short-term clearance of inhaled soluble uranium. These data made it possible to reevaluate the urinary excretion of soluble uranium against the ICRP-30/54 biokinetic model (1979) and the Wrenn-Lipsztein-Bertelli recycling systemic model (1989; Durbin 1984). We found that a modified form of the Wrenn-Lipsztein-Bertelli model best fit the urinary uranium excretion data. Our modifications included a shorter retention half-time ( 45 minutes instead of 12 hours) for uranium in the pulmonary lung compartment, and a 6-day reten-tion half-time (rather than 15-day) for uranium in the kidneys. This modi-fied Wrenn model was then used to estimate intakes, organ doses, and the committed effective dose equivalents for the workers.

We estimated the uranium intakes for 31 SFC workers, the resulting committed effective dose equivalents, the maximum kidney concentrations, and the long-term integral kidney retention. We also calculated the dose equivalents to bone surfaces, kidneys, and the lung, which are the organs receiving the highest radiation absorbed doses after inhalation of soluble uranium. Estimates of uranium intake by SFC workers ranged from 470 to $24,000 \mu \mathrm{g}$ $(0.47-24 \mathrm{mg})$.

The derived NRC 40-hour intake limit of $9.6 \mathrm{mg}$ soluble uranium in a work-week was exceeded by eight of 31 workers. Estimates of the maximum kidney concentrations in SFC workers ranged from 0.048-2.5 $\mu \mathrm{g} \mathrm{U} / \mathrm{g}$ kidney tissue. No toxicological effects on the kidneys at or less than these amounts were observed among the workers.

Estimates of the resulting committed effective dose equivalents ranged from 10 to $480 \mu \mathrm{Sv}$ (1-48 mrem). The highest organ doses were to bone surfaces $(0.0053 \mathrm{~Sv}$ for worker E-23). Dose limits recommended by the ICRP for internal emitters were not exceeded. Neither the stochastic nor the nonstochastic annual. limit on intake (ALI) for uranium, recommended by the International Commission on Radiological Protection (ICRP 1979) was exceeded. The calculated committed effective dose equivalents were much less than the stochastic limit of $0.05 \mathrm{~Sv}(5 \mathrm{rem})$ to the whole body for internal emitters (ICRP 1977, : 979 ).

The physiological indicators studied to detect kidney tissue damage by uranium poisoning included tests for protein, casts and cells, urinary blood, specific gravity, $\mathrm{pH}$ of the urine, and blood urea nitrogen. Physical examination and pulmonary function test results over a two-year follow-up period were also evaluated. We concluded from review of the medical records and laboratory results that none of the workers sustained any observable adverse health effects from exposure to uranium associated with the accident.

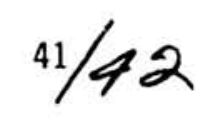




\section{REFERENCES}

Alexander, R. E. 1974. Applications of Bioassay for Uranium. WASH-1251. U.S. Atomic Energy Commission, U.S. Government Printing Office, Washington, D.C.

American Conference of Governmental Industrial Hygienists (ACGIH). 1986. Documentation of the Threshold Limit Values in Biological Exposure Indices, 5 th ed., p. 617. American Conference of Governmental Industrial Hygienists, Cincinnati, Ohio.

American Conference of Governmental Industrial Hygienists (ACGIH). Threshold Limit Values in Biological Exposure Indices for 1988-89. American Conference of Governmental Industrial Hygienists, Cincinnati, Ohio.

Durbin, P. W., and M. E. Wrenn. 1975. "Metabolism and Effects of Uranium in Animals." In Conference on Occupational Health Experience with Uranium, pp. 68-139, ERDA-93, Energy Research and Development Administration, Washington, D.C.

Dunford, D. W., and J. R. Johnson. 1987. GENMOD--A Program for Internal Dosimetry Calculations. AECL-9434, Atomic Energy of Canada Limited, Chalk River, Ontario.

Durbin, P. W. 1984. "Metabolic Models for Uranium." In Biokinetics and Analys is of Uranium in Man, pp. F-1-65. USUR-05/HEHF-47, Hanford Environmental Health Foundation, Richland, Washington.

Eve, I. S. 1966. "A Review on the Physiology of the Radiation Doses from Radioactive Materials." Health Phys. 12:173.

Fisenne, I. M., and G. A. Welford. 1986. "Natural U Concentrations in Soft Tissues and Bone of New York City Residents." Health Phys. 50:739-746.

Fisher, D. R. 1988. "Uranium." In Handbook on Toxicity of Inorganic Cumpounds, Chapter 68, pp. 739-748, ed. by H. G. Seiler and H. Sigel. Marcel Dekker, Inc., New York.

Gindler, J. E. 1973. "Physical and Chemical Properties of Uranium." In Uranium - Plutonium - Transplutonic Elements, Hodge, H. C., J. N. Stannard, and J. B. Hursh, eds, Chapter 2. Springer-Verlag, New York.

Hodge, H. C., et al. 1953. "MAC of Uranium Dust in Air." In Pharmacology and Toxicology of Uranium Compounds, p. 2247. McGraw-Hill Book Co., Inc., New York.

Hodge, H. C., J. N. Stannard, and J. B. Hursh, eds. 1973. Uranium - Plutonium - Transplutonic Elements. Springer-Verlag, New York. 
Hodge, H. C. 1973. "A History of Uranium Poisoning (1824-1942)." In Uranium - Plutonium - Transplutonic Elements, Hodge, H. C., J. N. Stannard, and J. B. Hursh, eds, Chapter 1, pp. 5-68. Springer-Verlag, New vnrk.

Howland, J. W. 1949. "Studies on Human Exposures to Uranium Co"pounds." In Uranium - Plutonium - Transplutonic Elements, Hodge, H. C., J. is. Stannard, and J. B. Hursh, eds, Chapter 16, pp. 993-10175-68. Springer-Verlag, New York.

Hursh, J. B., and N. L. Spoor. 1973. "Protection Criteria." In Uranium • Plutonium - Transplutonic Elements, Hodge, H. C., J. N. Stannard, and J. B. Hursh, eds, Chapter 5, pp. 241-270. Springer-Verlag, New York.

International Atomic Energy Agency (IAEA). 1978. Manual on Early Medical Treatment of Possible Radiation Injury. Safety Series No. 47, International Atomic Energy Agency, Vienna, Austria.

International Commission on Radiological Prutection (ICRP). 1975. Report of the Task Group on Reference Man. ICRP Publication 23. Pergamon Press, Oxford.

International Commission on Radiological Protection (ICRP). 1977. Recommendations of the International Commission on Radiological Protection. ICRP Publication 26. Pergamon Press, Oxford.

International Commission on Radiological Protection (ICRP). 1979. Limits for Intakes of Radionuclides by Workers. ICRP Publication 30, Part 1. Pergamon Press, 0xford.

International Commission on Radiological Protection (ICRP). 1988.

Individual Monitoring for Intakes of Radionuclides by Workers: Design and Interpretation. ICRP Publication 54. Pergamon Press, 0xford.

Kathren, R. L, J. F. McInroy, R. H. Moore, and S. E. Dietert. 1989. "Uranium in the Tissues of an Occupationally Exposed Individual." Health Phys. $57: 17-21$.

Kathren, R. L, and R. H. Moore. 1986. "Acute Accidental Inhalation of U: A 38-year Follow-up." Health Phys. 51:609-619.

Kocher, D. C. 1989. "Relationship Between Kidney Burden and Radiation Dose from Chronic Ingestion of U: Implications for Radiation Standards for the Public." Health Phys. 57:9-16.

Leggett, R. W. 1989. "The Behavior and Chemical Toxicity of $U$ in the Kidney: A Reassessment." Health Phys. 57:365-383.

Lincoln, T. A. and G. L. Voelz. 1988. "Management of Persons Accidentally Exposed to Uranium Compounds." Proc. of Medical Basis for Radiation Accident Preparedness, October 20-22, 1988, Oak Ridge, Tennessee (unpublished proceedings: the article is available from the author on request). 
Lipsztein, J. L. 1981. An Improved Model for Uranium Metablism in the Primate. Ph.D. Thesis. New York University Institute of Environmental Medicine. University Microfilms International, Ann Arbor, Michigan.

Morrow, P. E., L. J. Leach, F. A. Smith, R. M. Gelein, J. B. Scott, H. D. Beiter, F. J. Amato, J. J. Picane, C. L. Yuile, and T. G. Consler. 1982. Metabolic Fate and Evaluation of Injury in Rats and Dogs Following Exposure to the Hydrolysis Products of Uranium Hexafluoride. NUREG/CR-2268. University of Rochester, Rochester, New York.

Morrow, P. E. 1984. "Biokinetics and Toxicology of Uranium." In Biokinetics and Analys is of Uranium in Man, pp. E-1-27. USUR-05/HEHF-47, Hanford Environmental Health Foundation, Richland, Washington.

National Council on Radiation Protection and Measurements (NCRP). 1980. Management of Persons Accidentally Contaminated with Radionuclides. NCRP Report No. 65, National Council on Radiation Protection and Measurements, Washington, D.C.

National Council on Radiation Protection and Measurements (NCRP). 1985. General Concepts for the Dosimetry of Internally Deposited Radionuclides. NCRP Report No. 84, National Council on Radiation Protection and Measurements, Bethesda, Maryliand.

Stannard, J. N. 1988. Radioactivity and Health: A History. DOE/RL/01830-T59, National Technical Information Service, Springfield, Virginia.

United States Code of Federal Regulations. 1989. Title 10, Part 20, Standards for Protection Against Radiation. U.S. Government Printing Office, Washington, D.C.

U.S. Nuclear Regulatory Commission (NRC). 1986a. Assessment of the Public Health Impact from the Accidental Release of $U F_{B}$ at the Sequoyah Fuels Corporation Facility at Gore, Oklahoma. iain Report (Vol. 1) and Appendices (Vol. 2), NUREG-1189, U. S. Government Printing Office, Washington, D.C.

U.S. Nuclear Regulatory Commiszion (NRC). 1986b. Release of UF from a Ruptured Model 48Y Cylinder at Sequoyah Fuels Corporation Facility: LessonsLearned Report. NUREG-1198, U. S. Government Printing Office, Washington, D.C.

Widmann, F. K. 1983. Clinical Interpretation of Laboratory Tests, 9 th ed. F. A. Davis Co., Philadelphia.

Wrenn, M. E., W. P. Durbin, B. Howard, J. Lipsztein, J. Rundo, E. T. Still, and D. L. Willis. 1985. "Metabolism of Ingested Uranium and Radium." Health Phys. 48:601-633.

Wrenn, M. E., J. Lipsztein, and L. Bertelli. 1989. "Pharmacokinetic Models Relevant to Toxicity and Metabolism for Uranium in Humans and Animals." Radiation Protection Dosimetry 26:243-248. 
Yuile, C. L. 1973. "Animal Experiments." In Uranium - Piutonium - Transplutonic Elements, Hodge, H. C., J. N. Stannard, and J. B. Hursh, eds, Chapter 3. Springer-Verlag, New York. 


\section{AUTHORS}

Darrell R. Fisher is a Senior Research Scientist in the Exposure, Biokinetic and Dosimetric Modeling Group, Health Physics Department of Pacific Northwest Laboratory. Margery J. Swint, a medical doctor specializing in occupational medicine, is Manager of Personnel Health Services at the Hanford Environmental Health Foundation, and was previously Director of the United States Transuranium and Uranium Registries. Ronald L. Kathren is Director of the United States Transuranium and Uranium Registries and currently serves as President of the Health Physics Society. 


\begin{tabular}{|c|c|}
\hline $\begin{array}{l}\text { US NUCLEAR REGULATOHY COMMISSION } \\
\text { BIBLIOGRAPHIC DATA SHEET } \\
\text { (See. nstiuctions on the reverse) }\end{array}$ & \multirow[t]{2}{*}{ 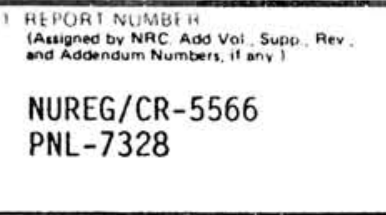 } \\
\hline \multirow{4}{*}{$\begin{array}{l}\text { Evaluation of Health Effects in Sequoyah Fuels Corporation } \\
\text { Workers from Accidental Exposure to Uranium Hexafluoride }\end{array}$} & \\
\hline & DATE REPOKT PUBLISHED \\
\hline & 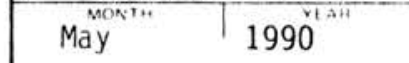 \\
\hline & $\begin{array}{l}\text { 4. FIN OR GAANT NUMB! A } \\
\text { B2487-8 }\end{array}$ \\
\hline \multirow[t]{2}{*}{ D. R. Fisher, M. J. Swint, and R. L. Kathren } & $\begin{array}{r}6 \text { TYPE OF REPORT } \\
\text { Technical }\end{array}$ \\
\hline & 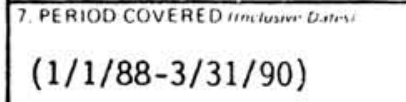 \\
\hline \multicolumn{2}{|c|}{ 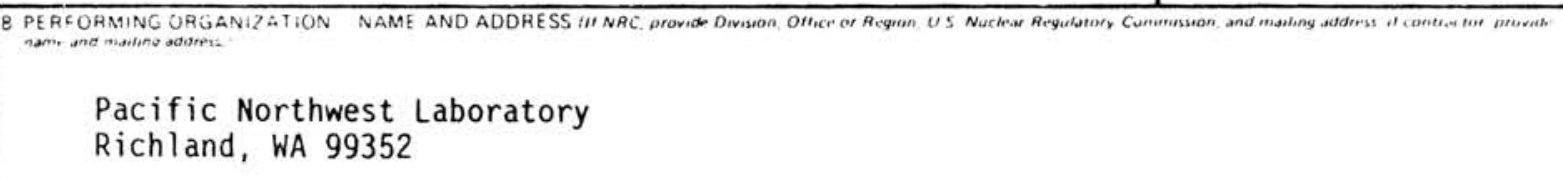 } \\
\hline \multicolumn{2}{|c|}{ 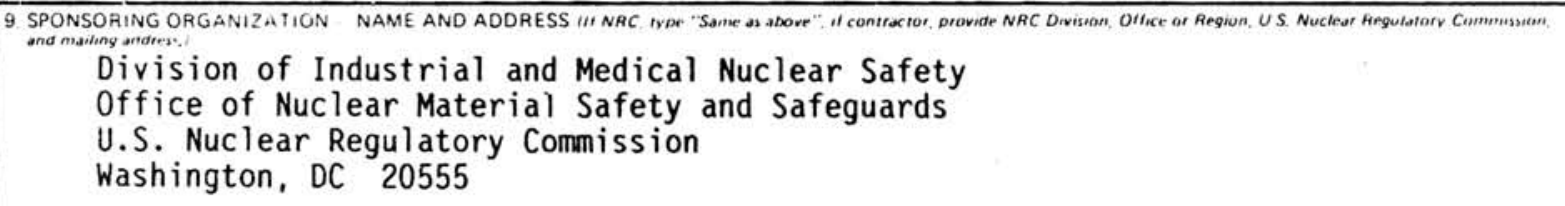 } \\
\hline \multicolumn{2}{|l|}{ 10. SUPPLEMENTARY NOTES } \\
\hline \multicolumn{2}{|l|}{ 11. ABSTRACT 200 wordos or ters) } \\
\hline \multicolumn{2}{|c|}{$\begin{array}{l}\text { Uranium urinalyses and medical laboratory results were studied to determine whether } \\
\text { there were any health effects from uranium intake among a group of } 31 \text { workers exposed } \\
\text { to uranium hexafluoride }\left(U_{6}\right) \text { and hydrolysis products following the accidental rupture } \\
\text { of a } 14 \text {-ton shipping cylinder in early } 1986 \text { at the Sequoyah Fuels Corporation uranium } \\
\text { conversion facility in Gore, Oklahoma. Physiological indicators studied to detect } \\
\text { kidney tissue damage included tests for urinary protein, casts and cells, blood, } \\
\text { specific gravity, and urine pH, blood urea nitrogen, and blood creatinine. We } \\
\text { concluded after reviewing two years of follow-up medical data that none of the } 31 \\
\text { workers sustained any observable health effects from exposure to uranium. The urinary } \\
\text { excretion data were used to develop an improved systemic recycling model for inhaled } \\
\text { soluble uranium. We estimated initial intakes, clearance rates, kidney burdens, and } \\
\text { resulting radiation doses to lungs, kidneys, and bone surfaces. Radiation dose limits } \\
\text { and limits on intake, as recomended by the ICRP, were not exceeded. However, the NRC } \\
\text { derived limit of } 9.6 \text { mg was exceeded by eight of the } 31 \text { workers. Maximum kidney } \\
\text { concentrations in exposed workers ranged from } 0.05 \text { to } 2.5 \text { g U/g kidney tissue. We } \\
\text { found no toxicological effects on the kidneys of workers at these concentrations. }\end{array}$} \\
\hline \multirow{5}{*}{ 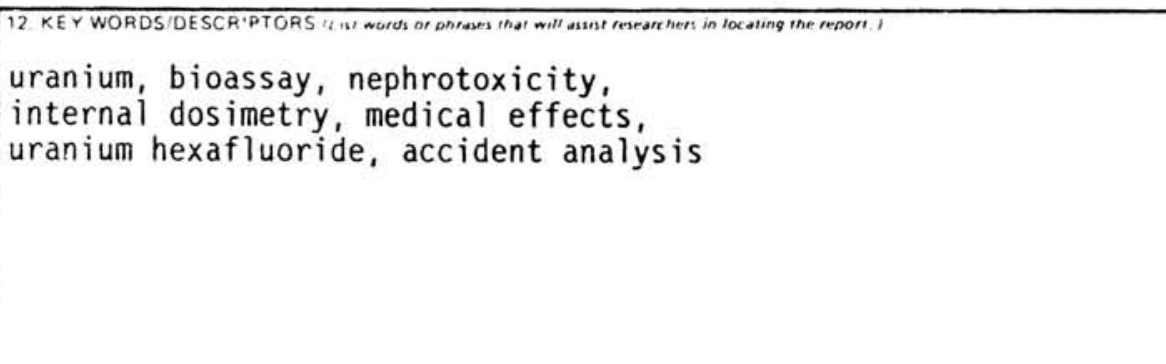 } & $\begin{array}{c}\text { B AVATLEBLITY STATEMENT } \\
\text { unlimited }\end{array}$ \\
\hline & $\begin{array}{l}\text { 14. SECUAITY CLASSIIICATION } \\
\text { "Thin Pay'lassified }\end{array}$ \\
\hline & $\begin{array}{l}\text { Then Repom } \\
\text { unclassified }\end{array}$ \\
\hline & 15 NUMBER OF PAGES \\
\hline & \\
\hline
\end{tabular}

NAC F CAM 3:5 1289 